\title{
ABBÂSÎLER DÖNEMİNİN İLK MEHDİSİ MUHAMMED B. ABDULLAH VE ONUN MEHDİLİĞİ İLE İLGİLİ RİVAYETLERİN DEĞERLENDİRİLMESİ
}

\author{
(1) Mithat ESER ${ }^{a}$
}

$\ddot{0} \mathbf{z}$

Tarih ve hadis kaynaklarımızda adaleti yeryüzüne hâkim kılacak kurtarıcı kişiyi ifade eden mehdinin farklı özelliklerini belirten rivayetler mevcuttur. "İsmi ismime, babasının ismi babamın ismine uygun" şeklinde tarif edilen mehdi hadisinin tarihte ilişkilendirildiği ilk kişi, Hz. Hasan'ın torunlarından "Nefsü'zZekiyye" lakaplı Muhammed b. Abdullah'tır. Böylece o, Abbâsî Devleti'ndeki ilk mehdi olarak kaynaklara yansımıștır. İlk defa Mugîre b. Saîd tarafından ona mehdi denildiği ve onun ilgili rivayeti delil olarak getirdiği görülmektedir. Dolayısıyla rivayetin Şiî eğilimli kaynaklara girişinin kaynağı burası olmalıdır. Öte taraftan aynı rivayetler, Üçüncü Abbâsî Halifesi Muhammed b. Abdullah için de kullanılmıştır. Hatta onun Mehdi lakabı kaynaklarımızda adının önüne geçmiştir. Böylece rivayetimiz Sünnî kaynaklarda da görülmeye başlamış ve hadis kaynaklarında ilgili mehdi rivayetleri yerini almıştır.

Sünnî kaynaklarda konumuzla ilgili olan mehdi rivayetleri, Ebû Dâvud ve Tirmizînin sünenlerinde ve başka hadis kaynaklarında geçmektedir. Dört farklı şekilde gördüğümüz hadis rivayetlerinin senetleri genel itibariyle zayıftır. Hasen olduğu kabul edilen bir rivayetin senedindeki Ebü'n-Nücûd Âsım b. Behdele'nin iyi bir kıraat âlimi olmakla birlikte hadisçiliğinde ihtilaf vardır.

Konumuzla ilgili mehdi rivayeti birçok tarih kaynağımızda nakledilmiştir. Ancak bunun, bazı tarihçiler tarafindan Muhammed Nefsü'z-Zekiyye, bazıları tarafından ise Üçüncü Abbâsî Halifesi Muhammed b. Abdullah ile ilişkilendirilmesi dikkat çekmektedir. Hatta söz konusu rivayetin Abbâsî Halifesi Müstekfî'nin oğlu Ebü'l-Hasan Muhammed b. Abdullah için de kullanıldığı ifade edilmiştir. Bu durum da hadis ilmi açısından zayıf olan rivayetin, tarihin farkhı dönemlerinde siyasete malzeme olarak kullanıldığını açıkça ortaya koymaktadır. Anahtar kelimeler: İslam Tarihi, Mehdilik, Muhammed Nefsü'z-Zekiyye, Halife Mehdi.

a Doç. Dr., Selçuk Üniversitesi, mithateser@hotmail.com 


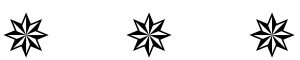

\section{MUHAMMAD B. ABDULLAH, THE FIRST MAHDI OF THE ABBASID PERIOD AND THE EVALUATION OF NARRATIVES ABOUT ITS MAHDIHOOD}

In our history and hadith sources, there are narrations stating the different characteristics of the mahdi, who expresses the savior who will establish justice on the earth. In the history, Muhammad b. Abdullah (nicknamed as Al-Nafs alZakiyya), who was the grandson of Hasan, was the first associated person with the definition of mahdi narration as "the name matches my name, the name of his father matches my father's name". Thus, he was mentioned in the sources as the first mahdi of the Abbasid State. It is seen for the first time that he was called as mahdi by Mughira b. Saîd and he claimed the relevant narration as evidence. Therefore, that should be the source of the entry of this narration into Shia sources. On the other hand, the same narration was also used for the third Abbasid Caliph, Muhammad b. Abdullah. Even his nickname 'Mahdi' has surpassed his name in our sources. Thus, this narration has started to be seen in Sunni sources as well, and the relevant mahdi narrations have taken place in hadith sources.

In Sunni sources, mahdi narrations related to our topic are mentioned in the Sunans of Abu Davud and Tirmidhi and in other hadith sources. We see the isnads of hadith narrations in four different forms which are generally weak. Abu-Nücûd Âsım b. Bahdala who is in the isnad of a narration which is accepted as a hasan (good), is a good qiraah scholar, but there is a controversy in his hadith profession.

Mahdi narration about our subject has been conveyed in many historical sources. However, it is noteworthy that some historians has associated this with Muhammad Al-Nafs al-Zakiyya and others by the third Abbasid Caliph, Muhammad b. Abdullah. In fact, it was stated that the relevant narration was also used for Abu'l-Hasan Muhammad b. Abdullah who was the son of Mustakfi, the Abbasid Caliph. This situation clearly reveals that the narration, which is weak in terms of hadith science, has been used as an instrument for politics in different periods of history.

[The Extended Abstract is at the end of the article.]

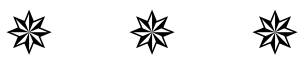

\section{Giriş}

Abbâsoğullarının Emevî Devleti'ne karşı başlattığı mücadele, Emevî Devleti'nin yıkılışı, Abbâsî Devleti'nin kuruluşu ile neticelenmiştir. Abbâsoğulları, hareketin gizli liderini ve devletin başına geçecek şahsı "erRıdâ min Âl-i Muhammed/Hz. Peygamber'in ailesinden herkesin razı olacağı 
biri" olarak vasıflandırıyorlardı. Bu, Hz. Peygamber'in amcaoğlunun soyu Abbâsoğulları ile amcaoğlu ve damadının soyu Alioğullarını kapsayan bir ifadeydi. Halk arasında hatta Kûfe'deki Ebû Seleme (öl. 132/750) gibi Abbâsoğullarının önemli davetçileri arasında bile yeni kurulacak olan devletin başına Alioğullarından birisinin geçmesi beklentisi vardı. Ancak yeni kurulan devletin başına Abbâsoğullarından Ebü'l-Abbâs es-Seffâh (öl. 136/754) geçti ve bu durum, taraftarlarıyla birlikte bazı Alioğulları arasında büyük bir hayal kırıklı̆̆ına sebep oldu. ${ }^{1}$

Abbâsî Devleti'nin ilk halifesi Seffâh ile Alioğulları arasında büyük mücadele ve çatışmalar yaşanmadı. Zira Seffâh devletin temellerini sağlamlaştırırken Alioğullarının önde gelen şahsiyetleri ile iyi geçinmeye çalışıyor, onlara atiyyeler veriyordu. Ancak kısa sürede Seffâh, Muhammed b. Abdullah en-Nefsü'z-Zekiyye (öl. 145/762) ile kardeşi İbrahim'den (öl. 145/763) endişe etmeye başlamıştır. Buna rağmen Seffâh, hutbelerde üstü kapalı bir şekilde Alioğullarını korkutma yoluna gitse de yaptığı yardımlarla onları yanına çekmeye çalışmıştır. ${ }^{2}$ Abbâsîlerin ikinci halifesi Ebû Ca'fer elMansûr (öl. 158/775) ise devleti sağlam temellere oturtmak ve otoritesini sağlamlaştırmak adına problem çıkaran ya da çıkarması muhtemel olan kişi ve gruplara karşı harekete geçti. Bu bağlamda ilk önce devletin kuruluşu esnasında önemli katkıları olan amcası Abdullah b. Ali'yi, daha da önemlisi Abbâsoğullarının Emevîlere karşı hareketini başlatan, Horasan davetçisi Ebû Müslim Horasânî̀yi yok etti. Mansûr'a göre, Alioğullarından, Hz. Hasan'ın soyundan Abdullah b. Hasan'ın oğulları özellikle Muhammed b. Abdullah devlet açısından büyük bir tehlike arz ediyordu. Bu sebeple Mansûr, Alioğullarına karşı fiili harekâtına başladı ve böylece Abbâsoğulları ile Alioğulları arasında ayrılı̆̆ı çıkaran ilk kişi oldu. ${ }^{3}$

Alioğulları cephesinden bakıldığında ise tam bir hayal kırıklığı söz konusu idi. Zira Hz. Ali'den (öl. 40/661) itibaren bu neslin önde gelen şahsiyetleri, bir yandan kendilerini idareye daha çok hak sahibi görürken öte yandan halkın bir kısmı onların iktidarda olmasını istiyordu. Bu sebeple $\mathrm{Hz}$. Hüseyin, (öl. 61/680) Zeyd b. Ali, (öl. 122/740) Yahya b. Zeyd (öl. 125/743) gibi bu neslin önde gelenleri, Emevîler döneminde halifeliğin zulmüne son vermek, adaleti tesis etmek adına Emevîlere karşı fiili hareketler

1 Nahide Bozkurt, Oluşum Sürecinde Abbâsî İhtilali (Ankara: Ankara Okulu Yayınları, 2000), 38-40.

2 Mithat Eser, Abbâsîlerin İlk Döneminde Seyyidler ve Şerifler (İstanbul: İz Yayıncılık, 2014), 101.

3 Celâlüddîn Abdurrahmân b. Ebî Bekr es-Süyûtî, Târîhu'l-Hulefâ', thk. Hamdi Demirtaş 
gerçekleştirmişlerdi. Abbâsoğullarının hilafetiyle birlikte iktidar olamayan Alioğullarının Muhammed b. Abdullah en-Nefsü'z-Zekiyye gibi bazı şahsiyetleri, mücadelelerini Abbâsî Devleti'ne karşı yürütmüşlerdir.

Muhammed b. Abdullah, Hz. Hasan (öl. 49/669) soyunun önemli şahsiyetlerinden birisiydi. 0 , önemli âlimlerden ders almış; hadisçilerin sika kabul ettiği, âlim, cömert, güçlü ve cesur bir kişiydi. Dindarlığından dolayı kişiliğinin temizliğini ifade eden "Nefsü'z-Zekiyye" ve "Mehdi"; soyunda hiç ümmü veled olmamasından dolayı "Saf Kureyşli' anlamında "Sarîhu Kureyş" lakaplarına sahipti. ${ }^{4}$ Öyle ki Abbâsoğulları ile Alioğullarının önde gelenlerinin Ebvâ'da bir toplantı yaptığı, toplantı sonunda Muhammed b. Abdullah'a biat edildiği ifade edilmektedir. ${ }^{5}$ Onun dinî ve ilmî yönü kadar siyasî hayatı da oldukça parlak idi. Toplum ve idareciler nezdinde onun itibarını anlatan birçok rivayet kaynaklarımıza yansımıştır. Onun siyasî arenada başlayan mücadelesi, farklı cephelerde kendini göstermiş ve $\mathrm{Hz}$. Peygamber'e yakınlık, nesep, Hz. Peygamber'in sözleri vb. dinî referanslar ile devam etmiştir. Bunlar arasında onun Mehdiliği önemli bir argüman olarak tarih kaynaklarımızda yer almış, hadis kaynaklarındaki rivayetlerle de bütünleștirilmiştir.

Alioğullarının önemli simalarından biri olan Muhammed b. Hanefiyye (öl. 81/700) ismiyle siyasî arenada ilk defa görülmeye başlayan Mehdilik konusu, o dönemden günümüze her devirde Müslümanların gündeminde yer alan bir vakıa olmuştur. İsnâaşeriyye Şîa'nın mehdiliği itikadî meselesi hâline getirmesi ile birlikte Mehdi algısı, Sünnî mezhebi mensupları tarafından da önemsenmiş, ortaya Mehdilik ile ilgili ciddi bir rivayet malzemesi çıkmıştır.

Buhârî (öl.256/870) ve Müslim'in (öl. 261/875) Sahîhlerinde Mehdi ile ilgili rivayet görülmemektedir. Ancak Ebû Dâvud (öl. 275/889) ve Tirmizînnin (öl. 279/892) sünenleri gibi kütüb-i sitte içinde yer alan diğer kaynaklarında ve başka hadis kaynaklarında mehdi rivayetleri geniş bir şekilde yer almaktadır. Bunlar içerisinde Abbâsîler dönemindeki ilk Mehdi olarak gördüğümüz Muhammed b. Abdullah'a uygun düşecek tarzda, “İsmi ismime, babasının ismi babamın ismine uygun" ifadesini içeren Mehdi rivayetleri dikkat çekmektedir. Öte yandan aynı ifadenin Abbâsî Halifesi

\footnotetext{
${ }^{4}$ Hayruddîn Ziriklî, el-A'lâm: Kâmûsu Terâcim li-Eşheri'r-Ricâl ve'n-Nisâ mine'l-Arabi'lMüsta'ribîn ve'l-Müsteșrikîn, 15. Bs (Beyrut: Dâru'l-Ilm li'l-Melâyîn, 2002), 6:220.

5 Ebü'l-Abbas Ahmed b. Yahyâ b. Câbir el-Belâzûrî, Ensâbü'l-Eşrâf, thk. Süheyl Zekkar ve Riyad ez-Ziriklî (Beyrut: Dârü'l-Fikr, 1996), 3:308; Alî b. el-Hüseyn Ebü'l-Ferec el-İsfahânî, Mekâtilü't-Tâlibiyyîn (Beyrut: Dâru'l-Marife, t.y.), 226; Cem Zorlu, Abbâsîlere Yönelik Dinî ve Siyasî Ísyanlar (Ankara: Ankara Okulu Yayınları, 2001), 222-224; M. Bahaüddin Varol, Hilafet Mücadelesinde Ehl-i Beyt Nesli (Konya: Yediveren Kitap, 2004), 76-80.
} 
Mehdî’ye (öl. 169/785) uygunluk arz ettiği de görülmektedir.

Mehdi rivayetleriyle ilgili birçok sened ve metin tenkidi çalışması ve rivayetlerle ilgili farklı görüşler bulunmaktadır. ${ }^{6} \mathrm{Bu}$ çalışmada "ismi ismime, babasının ismi babamın ismine uygun" ifadesinin yer aldığı mehdi rivayetleri sadece senet ve metin itibariyle değerlendirmekle kalmayacak, aynı zamanda söz konusu ifadelerin Muhammed Nefsü'z-Zekiyye başta olmak üzere kullanıldığı şahsiyetlerle ilgili tarihî rivayetler ele alınacaktır. Onların mehdiliğini ifade eden bu rivayetlerin, dönemin şartları içerisinde dinî ve siyasî hayatlarıyla ilgisi ortaya konulacaktır. Böylece ortamın, öncelikle Abbâsîlerin ilk mehdisi Muhammed b. Abdullah olmak üzere başka siyasî figürlerle ilgili rivayetleri ortaya çıkarışının izleri takip edilecektir.

\section{A. Muhammed b. Abdullah ile İlişkilendirilen Mehdi Rivayetlerinin Değerlendirilmesi}

Muhammed b. Abdullah en-Nefsü'z-Zekiyye ile ilişkilendirilen mehdi rivayetlerinde karşılaştığımız "ismi ismime, babasının ismi babamın ismine uygun" şeklinde geçen ifade, üzerinde durulması gereken bir husustur. Söz konusu ifadenin yer aldığı rivayet, hadis kaynaklarında iki farklı metinle nakledilmektedir. Bunlardan birincisi Ebû Dâvud ve Tirmizînnin eserlerindeki rivayettir:

1. Rivayet: Süfyân, Zâide, Fıtr gibi ravilerin tamamının aynı manada Âsım > Zir > Abdullah b. Mes'ûd'dan rivayet ettiğine göre Hz. Peygamber şöyle buyurmuştur: Dünyanın son günü olsa dahi (Zâide rivayetinde dedi ki:) Allah o günü uzatır (Bütün raviler ittifak etti ki) Allah benden veya ehl-i beytimden bir adam gönderir. Onun ismi ismime, babasının ismi babamın ismine uygundur. (Fitr'ın rivayetinde şu ilave vardır:) 0 , zulüm ve haksızlık dolu olan yeryüzünü adalet ve hakkaniyetle doldurur. (Süfyân rivayetinde şu da vardir:) Ehl-i beytimden ismi ismime uygun bir adam, Arapların idaresini alıncaya kadar dünya yok olmaz veya son bulmaz. Ebû Dâvud, Ömer ile

${ }^{6}$ Ebû Zeyd Veliyyüddîn Abdurrahmân b. Muhammed el-Hadramî el-Mağribî et-Tûnis İbn Haldûn, Kitâbü'l-Iber ve Dîvânü'l-Mübtede' ve'l-Haber fî Eyyâmi'l-Arab ve'l-Acem ve'lBerber ve men-Âsârahüm min-zevi's-Sultâni'l-Ekber (Beyrut: Dâru'l-Fikr, 1988), 1:388405; Celâlüddîn Abdurrahmân b. Ebî Bekr es-Süyûtî, el-Urfü'l-Verdî fî ahbârri'l-Mehdî (Beyrut: Dâru'l-Kütübi'l-Ilmiyye, 2006); Abdülalîm Abdülazîm Bestevî, el-Mehdiyyü'lMüntezar fî Davi'l-Ehâdîs ve'l-Âsâri's-Sahîha (Mekke: Dâru İbn Hazm, 1999); Mehmet Ali Durmuş, Mitolojik Kurtarıcı Mehdi, 2. Bs (İstanbul: İşaret Yayınları, 2015); Avni İlhan, "Kütübü Sittedeki Hadislere Göre Mehdilik", Dokuz Eylül Üniversitesi İlahiyat Fakültesi Dergisi, 7 (1992): 101-124; Ahmet Yücel, "Mehdi Hadislerinin Temel Kaynaklarındaki Anlamı", Beklenen Kurtarıcı İnancı, Editör: Yusuf Şevki Yavuz (İstanbul: Kuramer Yayınlarl, 2017), 141-173. 
Ebûbekir'in rivayeti Süfyân ile aynı manadadır, ancak Ebûbekir, Araplar ifadesini rivayet etmedi, demiştir. ${ }^{7}$

Süfyân Sevrî > Âsım b. Behdele > Zir > Abdullah b. Mes'ûd rivayetine göre Hz. Peygamber şöyle buyurmuştur: "Ehl-i beytimden ismi ismime uygun bir adam, Arapların idaresini alıncaya kadar dünya yok olmaz." Tirmizî, rivayet için sahih hasen demiştir. ${ }^{8}$ Tirmizî bu manada Hz. Ali, Ebû Saîd, Ümmü Seleme ve Ebû Hureyre'den rivayetler var demekte ve aynı yerde Ebû Hureyre rivayetini vermektedir. Ancak bu rivayetlerde "İsmi ismime uygun..." veya "İsmi ismime, babasının ismi babamın ismine uygun..." ifadesi geçmemektedir. Nuaym b. Hammâd'ın (öl. 228/843) eserinde aynı senedle yer alan rivayette Hz. Peygamber şöyle buyurmuştur: "Mehdi'nin ismi ismime, babasının ismi babamın ismine uygundur." Abdullah b. Mes'ûd, $\mathrm{Hz}$. Peygamber'i birçok defa babasının ismi ibaresini söylemeksizin duyduğunu söylemiștir."

İlk rivayetimizin senedindeki Abdullah b. Mes'ûd, Zir b. Hubeyş ve Âsım b. Behdele (Ebü'n-Nücûd)'den oluşan ilk üç ravi, "İsmi ismime, babasının ismi babamın ismine uygundur." ifadesinin yer aldığı kütüb-i sittede geçmeyen diğer rivayetlerde de aynıdır. İlk üç tabakada rivayet birer kişiden rivayet edilmiştir. Âsım'dan sonra hadisi birçok kişi rivayet etmiştir. Zir b. Hubeyş, tabiûn neslinden muhadram olan Kûfeli önemli bir şahsiyettir. ${ }^{10}$ Özellikle hocası Abdullah b. Mes'ûd'un kendisine bilgi soracağı derecede Arapçası; kendisinden rivayette bulunan Âsım b. Behdele'nin "Ondan daha çok Kur'an'ı bilen (kârî) bilmiyorum." dediği ve Abdullah b. Mes'ûd'un okuyușu üzerine Kur'an-ı Kerim'i baștan sona kendisine okuyacağı şekilde Kur'an kıraati iyi olan birisiydi. ${ }^{11}$ Hadisçiliği ile ilgili İbn

\footnotetext{
7 Ebû Dâvud, Mehdi, 1; Ebû Bekr Abdullâh b. Muhammed el-Absî el-Kûfî İbn Ebî Şeybe, Müsnedü İbn Ebî Seybe (Riyad: Dâru'l-Vatan, 1997), 1:192 Hadis No: 283; Ebûbekir Ahmed b. Amr el-Basrî el-Bezzâr, Müsnedü'l-Bezzâr (Medine: Mektebetü'l-Ulûm ve'l-Hıkem, 2009), 4: 204-206 Hadis No: 1803-1808; Ebû Abdillâh Ahmed b. Hanbel, Müsnedü Ahmed (Beyrut: Müessesetü'r-Risâle, 2001), 6: 42, 45, 7: 174, 311.

8 Tirmizî, Fiten, 52.

9 Ebû Abdillâh el-Huzâî el-Mervezî Nuaym b. Hammâd, Kitâbü'l-Fiten (Kahire: Mektebetü't-Tevhîd, 1412), 1:367 Hadis No: 1076-1077.

10 Ebü'l-Haccâc Cemâlüddîn Yûsuf b. Abdirrahmân el-Mizzî, Tehzîbü'l-Kemâl fî Esmâi'rRicâl (Beyrut: Müessesetü'r-Risâle, 1980), 9:335-336.

11 Ebû Abdillâh Muhammed İbn Sa'd, et-Tabakâtü'l-Kübrâ (Beyrut: Dâru'l-Ilmiyye, 1990), 6:162; Ebû Abdillâh Şemsüddîn Muhammed b. Ahmed ed-Dımaşkî ez-Zehebî, Tehzîbü Tehzîbi'l-Kemâl fî Esmâi'r-Ricâl (Kahire: el-Fârûku'l-Hadîsiyye li't-Tıbâati ve'n-Neşr, 2004), 3:283.
} 
Sa'd (öl. 845) ve İbn Ebî Hâtim'in (öl. 327/938) sika dediği bir raviydi.12 Ancak hemen hemen bütün kaynakların ifade ettiği onun Hz. Ali taraftarı oluşu, konumuz açısından önem arz eden bir ayrıntıdır. Âsım'ın anlattığına göre Zir b. Hubeyş, Ebû Vâil'den yaşça büyüktür ve ikisi bir arada iken Zir'in yanında Ebû Vâil rivayette bulunmazdı. Zir, Hz. Ali'yi Ebû Vâil ise Hz. Osman'ı severdi ancak bir araya geldiklerinde Âsım onların bu konudan bahsettiklerini hiç duymadığını söylemiştir. ${ }^{13}$ Zir, Hz. Ali'den rivayette de bulunmuştur. ${ }^{14}$

Rivayetimizin senedindeki 3. ravi Âsım b. Ebü'n-Necûd Behdele'dir. Hocası Zir gibi Kûfeli ve tabiûndan olan Âsım, meşhur yedi kıraat imamından birisidir. ${ }^{15}$ Zir gibi Âsım da hadisçiliğinden önce kıraatteki otoritesiyle tanınan birisidir. Hadisteki yeri hakkında ise farklı değerlendirmeler mevcuttur. İbn Sa'd, onun sika olduğunu ancak hadiste çok hata yaptığının söylendiğini ifade etmektedir. ${ }^{16}$ Ebû Zür'a (öl. 264/878) onun sika olduğunu kabul eder, ${ }^{17}$ İbn Hıbbân (öl. 354/965) onu sika ravileri aldığı eserine alır. ${ }^{18}$ Ebû Hâtim, (öl. 277/890) “İbn Uleyye onunla ilgili olumsuz söz söylemiş iken ona sika denilmesi uygun değildir, ismi Âsım olan her ravi seyyiü'l-hıfzdır, mahallühû es-sıdk (Böylesine sâdık denebilir.) ve salihu'l-hadistir, hafız değildir." demiştir. ${ }^{19}$ Onun hadislerinde münkerlik olduğu nakledilmiştir. ${ }^{20}$ Yahya b. Maîn (öl. 233/848) leyse bi'l-kaviy (kuvvetli değil) leyse bihi be’sün/lâ be'se bihi (zararı yok) görüşündedir. ${ }^{21}$ Ahmed b. Hanbel, (öl.

12 İbn Sa'd, Tabakât, 6:162; Ebû Muhammed Abdurrahmân b. Muhammed er-Râzî İbn Ebî Hâtim, el-Cerḥ ve't-Ta'dîl (Haydarâbâd: Tab'atü Meclisi Dâireti'l-Meârifi'l-Osmânî, 1952), $3: 622$.

13 İbn Sa'd, Tabakât, 6:12; Ebü'l-Kâsım Alî b. el-Hasen ed-Dımașkî eş-Șâfiî İbn Asâkir, Târîhu Medîneti Dımeșk, thk. Ömer b. Garâme el-Amravî (Beyrut: Dâru'l-Fikr, 1995), 19:29.

14 İbn Asâkir, Târîhu Medîneti Dımeșk, 19:25.

15 Zehebî, Tehzîbü Tehzîb, 5/5; Mehmet Ali Sarı, “Âsım b. Behdele”, TDV İslâm Ansiklopedisi (İstanbul: TDV Yayınları, 1991), 3: 475-476.

16 İbn Sa'd, Tabakât, 6/317.

17 Ubeydullâh b. Abdilkerîm er-Râzî Ebû Zür'a, Kitâbü'd-Duafâ' (Medine: Imâdetü'lBahsi'l-Ilmî, 1992), 3:885.

18 Ebû Hâtim Muhammed b. Hibbân el-Büstî İbn Hıbbân, Kitâbü’s-Sikât (Haydarâbâd: Dâiratü'l-Meârifi'l-Osmâniyye, 1973), 7:257.

19 İbn Ebî Hâtim, el-Cerh ve't-Ta'dîl, 1:341.

20 İbn Asâkir, Târîhu Medîneti Dımeșk, 25:239; Ebû Abdillâh Semsüddîn Muhammed b. Ahmed ed-Dımaşkî ez-Zehebî, Mîzânü'l-I'tidâl fî Nakdi'r-Ricâl, thk. Ali Muhammed elBicâvî (Beyrut: Dârü'l-Ma'rife, 1963), 2:357.

21 İbn Ebî Hâtim, el-Cerh ve't-Ta'dîl, 1:342; Ebû Hafs Ömer b. Ahmed el-Bağdâdî İbn Şâhîn, Târîhu Esmâi's-Sikât, thk. Subhî es-Sâmerrâî (Kuveyt: ed-Dâru's-Selefiyye, 1984), 1:150; İbn Asâkir, Târîhu Medîneti Dımeșk, 25: 228, 237. Bunlardan ilki cerh, sonraki ikisi ise dördüncü dereceden ta'dîl ifadesidir. Bk. Emin Așıkkutlu, "Cerh ve Ta'dîl”, TDV İslâm Ansiklopedisi (İstanbul: TDV Yayınları, 1993), 7: 398. 
241/855) oğluna onun faziletli ve ibadet ehli olduğunu, onun kıraatteki üstün konumunu ifade etmiş ancak Şu'be'nin, hadis noktasında A'meş'i Âsım'a tercih ettiğini söylemiştir. ${ }^{22}$ Dârekutnî, (öl. 385/995) Âsım'ın hadisçiliği ile ilgili ihtilaf olduğunu söylemektedir. ${ }^{23}$ Ukaylî, (öl. 322/934) edDuafâü'l-Kebir ${ }^{24}$ isimli eserinde Şu'be'den nakille, içinden geldiği gibi bize hadis rivayet etmiştir, der. Hadisçiliğinin sorunlu olduğu, özellikle Zir ile Ebû Vâil'den rivayet ederken karıștırdığı, aynı rivayeti bazen Zir'den bazen Ebû Vâil'den rivayet ettiği hatta bunu aynı günde yapıp sabah birinden akşam öbüründen rivayette bulunduğu ifade edilmektedir. ${ }^{25}$ Iclî de (öl. 261/875) bu durumu örnek bir rivayetle anlatır ve Hammâd b. Zeyd'in "Âsım > Ebû Vâil > Abdullah b. Mes'ûd" șeklinde verdiği senedi, Kûfelilerden biri "Âsım > Zir > Abdullah b. Mes'ûd" şeklinde vermektedir, der ve onun Zir ile Ebû Vâil'i karıştırdığı konusunda başka örnekler olduğunu söyler. ${ }^{26}$ İbn Hıbbân’a göre Âsım, hayatının son döneminde karıștırmıştır. ${ }^{27}$ Âsım'ın hadis konusundaki sıkıntıları sebebiyle olacak ki Buhârî ve Müslim Sahîhlerinde onun yer aldığı sadece iki rivayete yer vermişler, ${ }^{28}$ ancak bunları da mütâbaat için eserlerine almışlardır. ${ }^{29}$ Zehebî, (öl. 748/1348) onunla ilgili sebt (doğru) değerlendirmesinin bir derece altında, sadûkun yehimü (yanılır bir saduk) ve hasenü'l-hadis değerlendirmesinde bulunmuștur. ${ }^{30}$ Onu cerh ve ta'dîl edenleri ayrı ayrı veren Bestevî, raviyle ilgili Zehebî'nin kanaati olan hasenü'l-hadiste karar kılar. ${ }^{31}$ Bestevî, beş tarikten oluşan dört ayrı rivayetten oluşan aynı manadaki bu rivayet ile ilgili sahih ligayrihi ve hasen

${ }^{22}$ Ebû Abdillâh Ahmed b. Hanbel, el-Ilel ve Ma'rifeti'r-Ricâl, thk. Vasıyyüllâh b. Muhammed Abbâs, 2. Bs (Riyad: Dâru'l-Hânî, 2001), 3: 25, 54, 120; İbn Asâkir, Târîhu Medîneti Dımeşk, 27: 239.

23 Ebü'l-Hasen Alî b. Ömer Dârekutnî, el-Ilelü'l-Vâride fî Ehâdîsi'n-Nebeviyye, thk. Mahfûzurrahmân Zeynullah es-Selefî (Riyad: Dâru Taybe, 1985), 6: 212, 7: 70, 8: 169.

${ }^{24}$ Ebû Ca'fer Muhammed b. Amr Ukaylî, ed-Duafâü'l-Kebîr, thk. Abdülmu'tî Emin el-Kal'acî (Beyrut: Dâru'l-Mektebeti'l-Ilmiyye, 1984), 3: 336.

25 İbn Asâkir, Târîhu Medîneti Dımeșk, 25: 240; Ebü'l-Ferec Zeynüddîn Abdurrahmân b. Ahmed İbn Receb el-Hanbelî, Şerhu Ileli't-Tirmizî (Zerkâ: Mektebetü'l-Menâr, 1987), 2: 788.

26 Ebü'l-Hasen Ahmed b. Abdillâh el-Iclî, Târîhu's-Sikât (Mekke: Dâru'l-Bâz, 1984), 1: 240.

27 Ebû Hâtim Muhammed İbn Hıbbân, el-Mecrûhîn mine'l-Muhaddisîn, thk. Hamdî Abdülmecîd es-Selefî (Riyad: Dâru's-Sumayî, 2000), 12: 60.

28 İbn Asâkir, Târîhu Medîneti Dımeșk, 25: 220-221.

${ }^{29}$ Ebû Abdillâh Şemsüddîn Muhammed b. Ahmed ed-Dımaşkî ez-Zehebî, Siyeru A'lâmi'nNübelâ, thk. Şuayb el-Arnaût (Beyrut: Müessesetü'r-Risâle, 1985), 5: 260; Ebu'l-Fadl Ahmed b. Ali İbn Hacer el-Askalânî, Tehzîbü't-Tehzîb (Hindistan: Matbaatü Dâireti'lMeârifi'n-Nizâmiyye, 1326), 5: 39.

30 Zehebî, Mîzânü'l-I'tidâl, 2: 357.

31 Bestevî, el-Mehdiyyü'l-Müntezar, 247-249. 
sonuçlarına ulaşmıştır. ${ }^{32}$ Sonuç itibariyle Âsım'ın tefsir ve kıraat ile ilgili konularda rivayetleri alınır, ancak diğer konulardaki hadis rivayetlerinde tıpkı Buhârî ve Müslim'in yaptığı gibi mütâbaat veya şahit için alınabilir. Bir başka ifadeyle konumuzla ilgili rivayette olduğu gibi onun hadis rivayetleri, fert olduğunda zayıf olmaktadır. Dolayısıyla zayıf rivayetlerle inanç konusu temellendirmek doğru görünmemektedir.

Rivayete raviler tarafından ilaveler yapıldığı metinden açık bir şekilde anlaşılmaktadır. Ebû Dâvud rivayetinde "Allah benden veya ehl-i beytimden bir adam gönderir. Onun ismi ismime, babasının ismi babamın ismine uygundur." ifadesinde bütün ravilerin ittifak ettiği ifade edilirken, rivayetin devamında Süfyân rivayetinde yer alan "Ehl-i beytimden ismi ismime uygun bir adam..." ifadesi ile uyum gösteriyor gibi ise de rivayetin başı ile çelişmektedir. Tirmizî'nin rivayetinde de "Ehl-i beytimden ismi ismime uygun bir adam..." ifadesi bulunmaktadır. Birisi daha ayrıntılı birisi ise özet gibi görünen ifadelerdeki farklılık hakikatte farklı kişileri işaret etmektedir. Birinci isim Muhammed b. Abdullah ikinci isim ise baba ismi söylenilmeyen Muhammed olmaktadır. Bu farklılık Ehl-i Sünnet ile Şîa mezhepleri arasındaki bir ihtilafa dönüşmüş ve bazı Sünnî âlimler Mehdi'nin isminin Muhammed b. Abdullah olduğunu söylerken ${ }^{33}$ bazı Şiî âlimler ilk ibarenin mahfuz olmadığı, ikinci ibarenin bulunduğu rivayetlerin sahih olduğu görüşünü benimsemişlerdir. İkinci grup "babasının ismi babamın ismine uygun" ibaresinde tashîf (birbirine benzeyen harflerden oluşan kelimelerin nokta veya harekelerinin değiştirilerek yazılması) olabileceği, "ebî" kelimesinin aslının "ibn" olmasının mümkün olduğu ve noktalamanın olmadığı bir dönemde okuma yanlışlığı neticesinde "ebî" kelimesine dönüştüğü ihtimalini gündeme getirir. Aynı grup rivayet sahih olsa bile baba kelimesinin öz baba anlamına gelmediğini, dede veya ata anlamına gelebileceğini ayet ve hadislerle izah ederler. ${ }^{34}$ İki taraf arasındaki karşılıklı restleşme, rivayetin sıhhat durumuna odaklanmaktan ziyade karşı tarafın fikrini çürütmeye yönelik çatışmaya sebep olmuştur. Dolayısıyla taraflar, rivayetlerin sihhat durumunu ortaya koymak yerine Muhammed b. Abdullah veya On İkinci İmam Muhammed b. Hasan olduğunu ortaya koymak için bir çaba sarf etmişlerdir. Gerçi İbn Teymiye (öl. 728/1328) rivayetin âhâd

32 Bestevî, el-Mehdiyyü'l-Müntezar, 262-268.

33 Ebü'l-Abbâs Takıyyüddîn Ahmed b. Abdilhalîm İbn Teymiye, Minhâcü's-Sünneti'nNebeviyye, thk. Muhammed Reşad Sâlim (Riyad: Câmiatü'l-İmam Muhammed b. Suudü'lİslamiyye, 1986), 4: 95; Ebü'l-Hasen Nûrüddîn Ali el-Kârî, Mirkâtü'l-Mefâtîh Şerhu Mişkâtü'l-Mesâbîh (Beyrut: Dâru'l-Fikr, 2002), 8: 3438-3439.

34 Ebû Muhammed el-Bâkır Muhsin el-Emîn, A'yânü'ş-Şîa, thk. Hasan el-Emîn (Beyrut, 1986), 2: 50. 
olduğunu, imanın olmazsa olmazı olan dinin asıllarının bu tür rivayetlerle ortaya konulamayacağını da söylemektedir. 35 Aynı rivayetin Ebûbekir tarikinde "Araplar" ifadesi geçmemekte denirken, Tirmizînin rivayetinde "Araplar" ibaresi geçmektedir. Rivayetin metniyle ilgili bu ihtilaflar, rivayetlerin birbirini desteklemesi değil birbiriyle çelişmesi anlamına gelmekte, kanaatimize göre rivayetin hasen değil de zayıf bir rivayet olmasına sebebiyet vermektedir.

Âsım b. Behdele (Ebü'n-Necûd) sebebiyle zayıf olan bu rivayet ile ilgili dikkat çeken diğer bir husus ilk üç ravinin Kûfe bölgesinde yaşayan kişiler olmasıdır. ${ }^{36}$ Zir b. Hubeyş'in Hz. Ali taraftarı olduğu da düşünüldüğünde söz konusu rivayetin, özellikle çalışmamıza konu olan "ismi ismime, babasının ismi babamın ismine uygun" kısmının Hz. Ali taraftarlarınca uydurulması hiç de uzak bir ihtimal olmasa gerektir. Üstelik ilk defa mehdi kavramının sınırlı da olsa bilindiği ve kullanıldığı yer bu bölgedir. ${ }^{37}$ Zira konumuz itibariyle ortaya koyacağımız gibi Muhammed b. Abdullah ile ilişkilendirilen bu rivayetin sadece Kûfe'de biliniyor olması, söz konusu şahsın doğup büyüdüğü ve Abbâsî Halifesi Mansûr'a karşı harekete geçtiği Medine'de hem de rivayetlerin membaı olan bir şehirde bilinmemesi, duyulmaması anlamına gelmektedir ki bu da çok garip bir durumdur.

2. Rivayet: Velid ve Rișdîn > İbn Lehîa > İsrail b. Abbâd > Meymûn elKaddâh > Ebü't-Tufeyl senediyle rivayet edildiğine göre $\mathrm{Hz}$. Peygamber, Mehdi'yi tarif etti, dilinde kekemelik olduğunu söyledi ve yavaşça "İsmi ismim, babasının ismi babamın ismidir." sözünü söylerken sağ eliyle sol dizine vurdu. ${ }^{38}$

Ebü't-Tufeyl, Âmir b. Vâsile isminde en son vefat eden, Hz. Ali taraftarı ve Kûfe'de yaşamış bir sahâbîdir. ${ }^{39}$ Meymun el-Kaddâh isimli bir ravi tarafımızdan bulunamamıştır. Abdullah b. Meymun el-Kaddâh isminde çok zayıf bir ravi bulunmaktadır ancak onun da hocaları ile öğrencileri seneddeki

35 İbn Teymiye, Minhâcü's-Sünne, 4: 95.

36 Mehdi rivayetlerini hadis rivayeti coğrafyası açısından ele alan bir çalışmada Kûfeli ravilerin mehdi rivayetlerinin Ehl-i Beyt'ten bir kurtarıcıyı müjdelediği, diğer bölgelerin mehdi rivayetlerinin tipik özellikleri ve Hicaz bölgesinde mehdi rivayetlerinin nakledilmemesiyle ilgili bkz. Hüseyin Akgün, "Mehdilik Hadislerinin Hadis Rivayet Coğrafyası Açısından İncelenmesi", Hadis ve Siyer Araştırmaları Dergisi 5/2 (2019): 316. 37 Hüseyin Güneş, "İslam Tarihinin İlk Mehdisi: Muhammed b. Hanefiyye", Uluslararası Mehdilik Sempozyumu Bildirileri, ed. Mehmet Tiraşçı vd. (Sivas: Cumhuriyet Üniversitesi İlahiyat Fakültesi, 2018), 142-143.

38 Nuaym b. Hammâd, Fiten, 1: 365 Hadis No: 1069.

39 Mizzî, Tehzîbü'l-Kemâl, 14: 79-81; Zehebî, Tehzîbü Tehzîb, 4: 41; Ebu’l-Fadl Ahmed b. Ali İbn Hacer el-Askalânî, el-İsâbe fí Temyîzi's-Sahâbe, thk. Âdil Ahmed Abdülmevcûd-Ali Muhammed Muavvaz (Beyrut: Dâru'l-Kütübi'l-Ilmiyye, 1415), 7: 193. 
ravilerle tutmamaktadır. 40 İbn Ebî Hâtim, el-Cerh ve't-Ta'dîl adlı eserinde bu rivayetin sadece senedini vermekle yetinmektedir. ${ }^{41}$ Yani söz konusu ravinin kim olduğu bulunamamıştır.

Seneddeki Abdullah b. Lehîa, tedlis yapan, kitaplarından rivayet ederken onlar yandıktan sonra rivayeti işittiğini söylemesi "leyse bi şey" (hiçbir şey ifade etmeyen) olan ve bu esnada münker rivayetleri bulunan bir ravidir. Öncesinde işittiği rivayetlerin ise sahih olduğu ifade edilmektedir. ${ }^{42}$ Son dönemlerinde kendisine ait olmayan rivayetleri, birkaç raviden ve Iraklılardan rivayet ettiği ifade edilmektedir. ${ }^{43}$ Abdullah b. Lehîa gibi Mısırlı olan ve ondan rivayet eden Rişdîn b. Sa'd, münkeru'l-hadis, zaîfü'l-hadis gibi cerh lafızlarıyla tanımlanan bir ravidir. ${ }^{44}$

Nuaym b. Hammâd'ın Kitabü'l-Fiten isimli eserinde görülen bu rivayetin senedi son derece problemli, ravileri zayıftır. Kaldı ki Nuaym b. Hammâd'ın hadisçiliği de eleştirilmiştir. Konuyla ilgili makalesi bulunan Ali Çelik, onun bazı hoca ve öğrencilerini ele aldıktan sonra şöyle demektedir: "Nuaym b. Hammâd hakkında ileri sürülen bu üç farklı görüşün ağırlık noktası; onun, kişisel olarak güvenilir, abid ve salih bir kimse olmakla birlikte yaptığı rivayetleri konusunda aynı güvenilirliğe sahip olmadığı yönündedir. Onun hâlini araştırma konusunda ne kadar mütesâhil olunursa olunsun hemen bütün kaynaklar, onun hadislerinin alınamayacağı, delil olarak kullanılamayacağı konusunda ittifak halindedirler. Zira Nuaym b. Hammâd, çok yanılgan (kesirü'l-vehm), zayıf ve münkeru'l-hadis sahibi kimselerden nakillerde bulunan, bir kısım rivayetlerinde teferrüd etmiş, hatta bazı âlimlere göre sünneti koruma gayretiyle hadis uydurmuş olan bir şahsiyettir. Bütün bu vasıflar, bir hadis ravisinde bulunmaması gereken, onun güvenilirliğini giderici vasıflardır. Mücerred iyi niyet ve salih bir kişi olmak, hadisin sıhhati ve makbuliyeti için yeterli değildir." 45 Mehdi ile ilgili

\footnotetext{
40 Mizzî, Tehzîbü'l-Kemâl, 16: 198-202; Zehebî, Tehzîbü Tehzîb, 5: 326.

41 İbn Ebî Hâtim, el-Cerh ve't-Ta'dîl, 2: 331.

42 İbn Hıbbân, Mecrûhîn, 10: 504-507; Mizzî, Tehzîbü'l-Kemâl, 15: 490-491.

43 İbn Ebî Hâtim, el-Cerḥ ve't-Ta'dîl, 5: 146; Zehebî, Mîzânü'l-ítidâl, 2: 477; İbn Hacer elAskalânî, Tehzîbü't-Tehzîb, 5: 375.

44 Mizzî, Tehzîbü'l-Kemâl, 9: 191-195; Zehebî, Mîzânü'l-I'tidâl, 2: 49-51; İbn Hacer elAskalânî, Tehzîbü't-Tehzîb, 3: 278.

45 Ali Çelik, "Nuaym bin Hammâd'ın Hadisçiliği ve 'Kitâbu'l-Fiten'i Üzerine Bir Değerlendirme”, Dinî Araştırmalar 2/6 (2000): 108-109. Nuaym b. Hammâd'ın şahsiyetiyle ilgili olumlu ancak hadisçiliği ile ilgili olumsuz olduğu, hadisçiliğiyle ilgili olumsuz ifadelerinin yanı sıra "sünnet sahibi", "sünnette imam" gibi ifadelerin bulunduğunu ancak bunların mihne olaylarında Mutezili değil de Sünnî bir bakış açısıyla ilgili olduğu, ehl-i rey ve ehl-i eser tartışmalarıyla ilgili Nuaym'ın hadis bile uydurduğu ithamıla ilgili bkz. Muhammed Emin Eren, "Olgudan Rivayete Ya da Yorumun
} 
rivayetlerin sıhhatini araştıran ve sadece 8 tane rivayetin sahih veya hasen olduğunu söyleyen Bestevî de rivayetin zayıf olduğunu ve metninde "Mehdi'nin yedi yıl hüküm süreceği" ile ilgili bilgiye muhalif olduğunu söylemektedir. ${ }^{46}$ "Mehdi'nin ismi Muhammed b. Abdullah'tır ve dilinde kekemelik vardır." rivayetini Bestevî, rafizi ve hadis uydurmakla itham edilen Kelbî'den dolayı mevzu kabul etmektedir. ${ }^{47}$ Ammâr b. Yâsir'in naklettiği “Nefsü'z-Zekiyye ve kardeşi öldürüldüğünde gökten bir münadi, 'Emiriniz falandır. Bu kişi, yeryüzünü hak ve adaletle dolduracak olan Mehdi'dir.' diye seslenmiştir." rivayetinin de senedindeki Ebû Zür'a sebebiyle çok zayıf olduğu ifade edilmiştir. ${ }^{48}$

Böylesi bir kaynak ve rivayetle konumuz olan "ismi ismime, babasının ismi babamın ismine uygun" bir mehdi anlayıșı inanç ya da hüküm konusu olamaz. Üstelik rivayetin metninde geçen söz konusu Mehdi'nin kekeme oluşu, daha sonra başka rivayetlere de yansımış ve bu kişinin Muhammed Nefsü'z-Zekiyye b. Abdullah olduğu ifade edilmiștir. ${ }^{49}$ Ancak bunun Muhammed b. Abdullah'ın mehdiliğini birçok rivayetle ispatlamaya çalışan Hz. Ali $\operatorname{taraftar}^{50}$ Ebü'l-Ferec el-İsfahânî'ye ${ }^{51}$ ait bir algı olduğu dikkate

Rivayetleşmesi: Nu'aym b. Hammâd'a Ait Bir Rivayetin Tahlili", İslam ve Yorum -Temel Tartışmalar, Imkanlar ve Sorunlar-, ed. Fikret Karaman (Ankara: TDV Yayınları, 2017), 2: 656.

46 Abdülalîm Abdülazîm Bestevî, el-Mevsûa fî Ehâdîsi'l-Mehdî ed-Daîfeti ve'l-Mevdûati (Mekke: Dâru İbn Hazm, 1999), 122-123.

${ }^{47}$ Bestevî, el-Mevsûa, 150.

48 Bestevî, el-Mevsûa, 163.

${ }^{49}$ Ebü'l-Ferec el-İsfahânî, Mekâtilü't-Tâlibiyyîn, 214.

50 İslam Ansiklopedisi “Ebü’l-Ferec el-İsfahânî” maddesi yazarı, “Ebü’l-Ferec'in Şiî olduğu rivayet edilmekteyse de çağdaşları İbnü'n-Nedîm ile Ebû Nuaym el-İsfahânî, ayrıca kendisinden hadis rivayet eden Dârekutnî, Ali er-Rezzâz ve İbn Dûmâ gibi âlimler bu hususta herhangi bir şey söylemedikleri gibi bugüne ulaşan eserlerinde Şiîliğini gösterecek bir bilgiye de rastlanmamaktadır." demekte ve onun Şî̂lik iddiasının sadece bir müellifin bir ibareyi yanlıș okumasından kaynaklandığını ifade etmektedir. Bkz. Hulusi Kılıç, “Ebü'l-Ferec el-İsfahânî”, TDV İslâm Ansiklopedisi (İstanbul: TDV Yayınları, 1994), 10: 316-318.

51 Mekâtilü’t-Tâlibiyyîn eseri incelendiğinde onun İsnâașeriyye/Şia eğimli olmadığı söylenebilir. Henüz onun döneminde tam anlamıyla Şîa mezhebinin teşekkül etmediği de bilinmektedir. Ancak onun eseri incelendiğinde Hz. Ali taraftarı olduğu rahatlıkla görülecektir. Bu, Emevî karşıtlığından da kaynaklanabilir. Konumuzla ilgisi bakımından Muhammed b. Abdullah'ın mehdiliği ile ilgili “Onun Mehdi Olarak İsimlendirildiğine Dair Söylenenler" başlığı altında Muhammed b. Abdullah'ın iki omzunun arasında yumurta şeklinde siyah bir yuvarlağın bulunması, Ebû Ca'fer el-Mansûr'un ona büyük hürmet göstermesi ve 'Ehl-i beytimizin Mehdisi” demesi, Fatıma bt. Ali'nin Hz. Ali'nin ağzından en küçük çocuğunun Mehdi'yi göreceğine dair rivayet, Mehdi'nin dolayısıyla onun kekeme oluşuna dair rivayetleri verdikten sonra İsfahânî şöyle demektedir: "Muhammed b. Abdullah'ın mehdiliği konusunda birçok rivayet vardır. Söylediklerimiz onlardan bir kısmıdır." Ebü'l-Ferec el-İsfahânî, Mekâtilü't-Tâlibiyyîn, 211-217. 
alınmalıdır.

3. Rivayet: Bezzâr > İsmail b. Ebü'l-Hâris ve Ahmed b. Yahya es-Sûsî > Dâvud b. el-Muhabber b. Kahzem > el-Muhabber b. Kahzem > Kahzem b. Süleyman > Muaviye b. Kurre > babası Kurre senediyle;

Taberânî > Muhammed b. Abdûs b. Kâmil es-Sirâc > Ahmed b. Muhammed b. Nîzek > Ahmed b. Muhammed b. Sadaka > Muhammed b. Yahya el-Ezdî > Dâvud b. el-Muhabber b. Kahzem > Ebü'l-Muhabber b. Kahzem > Muaviye b. Kurre > babası Kurre senediyle;

Hz. Peygamber şöyle buyurmuştur: Adalet ve hakkaniyet dolu olan dünyayı zulüm ve haksızlık kaplayacak; nihayetinde Allah benden, ismi ismime, babasının ismi babamın ismine uygun bir adam gönderecektir. $O$, zulüm ve haksızlıkların kapladığı yeryüzünü adalet ve hakkaniyetle dolduracaktır. $O$, aralarında yedi, sekiz ya da en fazla dokuz yll kalacaktır. O, yeryüzünde bulunduğu müddetçe gökyüzü, rahmetini; yeryüzünü, bereketini eksik etmeyecektir. ${ }^{52}$

Taberânî (öl. 360/971) ve Bezzâr (öl. 292/905) rivayetinde metindeki son iki cümlede takdim tehir vardır. Her iki rivayetin senedindeki Dâvud b. el-Muhabber b. Kahzem, çok zayıf, metruk hatta hadis uyduran bir ravidir. Onun mevzu rivayetleri de cerh ve ta'dîl eserlerinde yer almıștır. ${ }^{53}$

4. Rivayet: Ebû Dâvud'a Harun b. Mugîre'den nakledildiğine (huddistü) göre, Amr b. Ebû Kays > Şuayb b. Halid > Ebû İshak senediyle şu rivayet nakledilmiştir: Bir gün Hz. Ali oğlu Hasan'a baktı ve "Allah Rasulü'nün isimlendirdiği gibi benim bu oğlum seyyiddir. Onun neslinden bir adam çıkacak, Peygamberinizin ismini alacak, ahlakı ona benzeyecek ancak fiziki benzemeyecek." dedi ve ardından Hz. Ali, yeryüzünü adalet ve hakkaniyetle dolduracak kişinin kıssasını anlattı. 54

Rivayet, gerek Ebû İshak'ın Hz. Ali'ye yetişmemesi ve ondan rivayette bulunmaması ${ }^{55}$ gerekse Ebû Dâvud'un "huddistü" ifadesini kullanması ve rivayeti aldığı kişinin isminin bilinmemesi sebebiyle munkatı' kabul edilmiștir. ${ }^{56}$ Benzer bir rivayet, Hammâd'ın Kitâbü'l-Fiteni'nde geçse de

52 Bezzâr, Müsned, 8: 257; Ebü'l-Kâsım Müsnidü'd-dünyâ Süleymân b. Ahmed Taberânî, Mu'cemü'l-Kebîr, thk. Hamdi Abdülmecit (Kahire: Mektebetü İbn Teymiye, 1994), 19: 32.

53 İbn Hıbbân, Mecrûhîn, 3: 424; İbn Hıbbân, Mecrûhîn, 7: 356; Mizzî, Tehzîbü'l-Kemâl, 8: 443-449; Zehebî, Tehzîbü Tehzîb, 3: 170-172.

${ }^{54}$ Ebû Dâvud, Mehdi, 1.

55 Ebü't-Tayyib Muhammed Şemsü'l-Hak b. Emîr Alî Azîmâbâdî, Avnü'l-Ma'bûd Şerhu Süneni Ebî Dâvud (Beyrut: Dâru'l-Kütübi'l-Ilmiyye, 1415), 11: 257.

56 Abdülmuhsin b. Hamd, Şerhu Süneni Ebî Dâvud (el-Mektebetü’ş-Şamile, t.y.), 23: 481. 
rivayetin senedinde birçok müphemlik bulunmakta ve rivayet zayıf kabul edilmektedir. ${ }^{57}$

Genel olarak rivayetlere bakıldığında özellikle Ebû Dâvud ve Tirmizî'nin yukarıda verdiğimiz rivayetleri, Mehdi ile ilgili bir bab başlığ altında zikredilse de bu rivayetlerde "Mehdi" ifadesinin geçmediği görülmektedir. Rivayetlerin senedlerinde problemli ravilerin olması ve rivayetlerin sened tekniği açısından zayıflığı çok bariz bir şekilde dikkat çekmektedir. Senedlerdeki dikkat çeken diğer bir husus genel olarak 'an fülan' (falandan nakledilmiştir) ifadesinin yer almasıdır. Söz konusu ifadenin ilk iki asırda semâ (dinleme) ifade ettiği, sonraki dönemlerde ihtilaflı olup birtakım şartlarla semâ anlamına gelebileceği zikredilmiştir. 58

"Mehdi rivayetlerinin bazı tarihî olaylar üzerine varit olduğuna dair önemli ipuçları mevcuttur. Örneğin siyah bayrak taşıyan bir ordunun Horasan yahut Doğu tarafından çıkıp Mekke'ye yürüyeceğini, bu ordu komutanının mehdi olduğunu, kar üzerinde sürünerek bile olsa bu orduya katılmanın gerekliliğini telkin eden rivayet bunlardan biridir. ${ }^{59}$ Oysa bu haberde Horasan'dan çıkıp Mekke'ye doğru gelen Abbâsî ordusundan söz edildiği açıktır." 60 "Dikkat edilirse bu rivayetlerde, 'tarihte vuku bulan olayların tasvir edilmesi'nin yanı sıra adrese teslim, 'ince detay'lar ve 'isimlendirme'ler oldukça fazla yer almakta, bu da merfu hadislerin formatına pek uygun düşmemektedir. Rivayetlerde bu kadar detay, şahıs ve coğrafî isimlerin yer alması güvenilirliklerine gölge düşürmektedir." 61

\section{B. İslam Tarihi Kaynaklarında Muhammed b. Abdullah'ın Mehdiliği}

Bu başlık altında özellikle tarih kaynaklarında Muhammed b. Abdullah en-Nefsü'z-Zekiyye'nin mehdi oluşu ile ilgili rivayetler ele alınacaktır. Böylece onun dinî ve siyasî hayatının, mehdiliği ile ilişkilendirilmesinin izleri takip edilmeye çalışılacaktır.

Görebildiğimiz kadarıyla ilk dönem tarih kaynakları arasında

57 Bestevî, el-Mevsûa, 347-348.

58 Abdullah Aydınlı, "Muan'an", TDV İslâm Ansiklopedisi (İstanbul: TDV Yayınları, 2005), 30: 326.

59 İbn Mâce, Fiten, 34.

60 Orhan Yllmaz, "Mehdi İnancına Kaynaklık Teșkil Eden Hadislerin Değeri", Turkish Studies International Periodical for the Languages, Literature and History of Turkish or Turkic 12/2 (2017): 277.

61 Cemal Ağırman, "Kütüb-i Tis'a Kaynaklarında Yer Alan Mehdî ile İlgili Rivayetlerin Değerlendirilmesi ve Bu Rivayetlerle İlgili Yapılan Yorumlar", Uluslararası Mehdilik Sempozyumu Bildirileri, ed. Mehmet Tıraşçı vd. (Sivas: Cumhuriyet Üniversitesi İlahiyat Fakültesi, 2018), 2: 338. 
Muhammed b. Abdullah'ın mehdiliğine değinen ilk müellif, Hz. Ali taraftarlığı ile tanınan Ya'kûbî̀dir (öl. 292/905) ve o, "Babası Abdullah'ın Muhammed'e Mehdi dediğini söylemektedir." 62 Benzer bir rivayete göre Abdullah, Ebü'lAbbâs'ın halife olarak belirlenmesinden önce oğulları Muhammed ve İbrahim'i halife adayı olarak görüyor, oğlu Muhammed'i "Mehdi" ve "Muhammed Nefsü'z-Zekiyye" olarak isimlendiriyordu. Ebvâ toplantısı olarak ifade edilen ve Abdullah'ın, halife olarak oğlu Muhammed'e biat etmeye çağırdığı bu toplantıda Ca'fer es-Sâdık, "Allah'tan kork! Kendini ve aileni kötülükten koru. Çünkü halifelik amcaoğullarımızın olacaktır. İllaki onlardan yüz çevireceksen hiç olmazsa kendin adına biat iste. Zira sen bu işe oğlundan daha layıksın." demiştir.63 Bu rivayeti nakleden Belâzurî, (öl. 279/892-893) Muhammed'e "Mehdi" diyenin, Becîle kabilesinin mevlası (azatlısı) ve Mugîriyye mezhebi kendisine nispet edilen Mugîre b. Saîd el-Iclî el-Becelî (öl. 119/837) olduğu rivayet edilmektedir, demektedir.64 Aynı iddiayı Safedî (öl. 764/1363) şöyle dile getirmektedir: "Muhammed b. Abdullah'ın öldüğüne ve katledildiğine inanmayan Şî̂ bir fırka olan Muhammediye'ye mensup Mugîre b. Saîd el-Iclî, beklenen Mehdi'nin (elMehdiyyü'l-Müntezar) Muhammed b. Abdullah olduğunu taraftarlarına söylemekte ve bu görüşüne de onun isminin Peygamber'in ismi, babasının isminin de babasının ismiyle uygunluğunu delil olarak getirmektedir. Üstelik o, 'Benden sonra bir adam gelecek, ismi ismime, babasının ismi de babamın ismine uygun olacaktır.' șeklindeki Peygamber sözünden kastedilen kişinin Muhammed b. Abdullah olduğunu söylemektedir."65 Taberî (öl. 310/923) ve aynı rivayeti veren İbnü’l-Esîr'e (öl. 630/1233) göre Medine Valisi Ziyâd b. Ubeydullah, yanında Muhammed b. Abdullah ile birlikte Medinelilere hitap ettiği zaman Medineliler "Mehdi! Mehdi!" diye bağırıp tezahürat yapiyorlard1. ${ }^{66}$

Tarih kaynaklarında özellikle ilk dönemde Muhammed b. Abdullah'ın mehdiliği ile ilgili rivayetlere rastlamaktayız. En erken dönem olarak Ya'kûbî'nin eseri görülmekle birlikte daha çok Hz. Ali taraftarı müelliflerin eserlerinde söz konusu mehdilik iddiasının yer alması dikkat çekmektedir.

\footnotetext{
${ }^{62}$ Ahmed b. Ebî Ya'kûb b. Ca'fer el-Ya'kûbî, Târihu'l-Ya'kûbî (Beyrut, 1995), 371.

63 Belâzûrî, Ensâbü'l-Eșrâf, 3: 307-308.

64 Belâzûrî, Ensâbü'l-Eşrâf, 3: 307.

65 Salâhuddîn Halil b. Aybek Safedî, Kitabü'l-Vâfi bi'l-Vefeyât, thk. Ahmed Arnaûd ve Mustafa Türkî (Beyrut: Dâru İhyâi't-Türâs, 2000), 3: 243.

66 Ebû Cafer İbn Cerîr Muhammed b. Cerîr b. Yezîd Taberî, Târîhu'l-Ümem ve'l-Mülûk, 2. Bs (Beyrut: Dâru't-Türâs, 1387), 7: 529; İzzuddin Ebu'I-Hasan Ali b. Muhammed İbnü'l-Esîr, el-Kâmil fi't-Târîh (Beyrut: Dâru'l-Kütübi'l-İlmiyye, 2010), 5: 101; Gülgün Uyar, Ehl-i Beyt, İslam Tarihinde Ali-Fatıma Evladı (İstanbul: Gelenek Yayınları, 2004), 163.
} 
Bununla birlikte Belâzurî, Taberî gibi ilk dönem İslam tarihinin temel eserlerinde de Muhammed b. Abdullah'ın mehdiliği bir şekilde yer almaktadır. Bu rivayetlerde Muhammed b. Abdullah'a mehdi lakabını veren kişilerle ilgili de farklı bilgiler mevcuttur. Rivayetlerden anlaşıldığı kadarıyla Mugîre b. Saîd'in mehdiye ilişkin ifadeleri baba Abdullah b. Hasan tarafından oğlu Muhammed için kullanılmaya başlanmış, zamanla Muhammed kendisi için kullanılan mehdi lakabına inanmış ve Ebû Ca'fer ile mektuplaşmalarında bunu kullanmıştır. Nitekim Muhammed Nefsü'z-Zekiyye ile Ebû Ca'fer elMansûr arasındaki mektuplaşmalarda Muhammed'in kendisine Mehdi lakabını verdiği açıkça görülmektedir. ${ }^{67}$ Muhammed b. Abdullah'ı tarif eden "ismi ismime, babasının ismi babamın ismine uygun" mehdi inancına giden yolun Mugîre b. Saîd tarafından başlatılması rivayeti şayet sahih ise, bunun bir benzeri Muhtar b. Ebû Ubeyd (öl. 67/687) ile Muhammed b. Hanefiyye arasında yaşandığ 168 ifade edilebilir. Zira siyasî olarak birtakım emelleri olan insanların hedeflerine ulaşabilmek için toplum nezdinde belli bir itibara sahip olan özellikle de Hz. Peygamber'in nesebinden gelen insanları Mehdi olarak takdim etmesinin ardında, kendilerinin Mehdi olarak sunulması yatmaktadır. Her ikisinde de Sâsânî kökenli bir kurtarıcı fikrinin önce Şî̂ bir düşünceye evrilmesi ${ }^{69}$ ardından da Sünnîliğin de kabul ettiği bir fikir hâline gelmesi dikkat çekmektedir. Bu arada "ismi ismime, babasının ismi babamın ismine uygun" mehdi inancının daha çok Hz. Ali taraftarlığı ön planda olduğu ifade edilen tarihçilerin kitaplarında yer alması çelişki gibi görünebilir. Ancak bu tip yazarların İsnâaşeriyye Şîa'sına mensup olmadıkları bir yana daha çok Emevî karşıtı olmaları dikkat çekmektedir.

Hz. Ali taraftarlığı dikkat çeken tarihçilerin, Muhammed b. Abdullah'ın mehdi oluşuna dair rivayetleri eserlerine aldığı görülmektedir. Bunlardan Mes'ûdî (öl. 345/956) "Muhammed b. Abdullah'a şehirli ve bedevi pek çok kişi biat etmiş, ona Mehdî unvanını vermiștir." demektedir. ${ }^{70}$ Mu'tezilî olduğu ifade edilen Makdisî, "Mehdinin Çıkışı" başlığı altında "Mehdi ile ilgili birçok farklı rivayet, Hz. Peygamber, Hz. Ali, İbn Abbâs ve diğer sahâbîlerden

67 Taberî, Târîhu'l-Ümem ve'l-Mülûk, 7: 567; Ebû Alî Ahmed b. Muhammed el-Hâzin İbn Miskeveyh, Tecâribü'l-Ümem ve Te âkibü'l-Himem, thk. Ebü'l-Kasım İmâmî, 2. Bs (Tahran: Serûş, t.y.), 3: 395; Ebû Abdillâh Şemsüddîn Muhammed b. Ahmed ed-Dımaşkî ez-Zehebî, Târîhu'l-İslâm, thk. Ömer Abdüsselâm et-Tedmürî, 2. Bs (Beyrut: Dâru'l-Kütübi'l-Arabî, 1993), 9: 24.

${ }^{68}$ Güneş, "Muhammed b. Hanefiyye”, 143-144, 155-156.

69 Fatih Topaloğlu, "Şîa'daki Mehdi İnancının Zerdüștlükle İlișkisi”, Uluslararası Mehdilik Sempozyumu Bildirileri, ed. Mehmet Tıraşçı vd. (Sivas: Cumhuriyet Üniversitesi İlahiyat Fakültesi, 2018), 102, 113.

70 Ebü'l-Hasan Ali b. Hüseyin el-Mes'ûdî, et-Tenbîh ve'l-İşrâf, thk. Abdullah İsmâil es-Sâvî (Kahire: Mektebetü'ş-Şarkı'l-İslâmiyye, 1938), 295. 
bir çok söz nakledilmiştir. Ancak bunların hepsiyle ilgili bir takım farklı görüşler vardır. Onu normal bir tabiat hadisesi olarak görenler açısından da durum aynıdır. Biz bu rivayetleri nakledeceğiz. İhtilaflı mehdi rivayetlerinin sıhhat açısından en sağlamı, Ebûbekir b. Ayyâş > Âsım > Zir > Abdullah b. Mes'ûd senediyle Hz. Peygamber'den nakledilen ,Ehl-i beytimden ismi ismime uygun bir adam ümmetime gelinceye kadar dünya son bulmayacaktır." rivayetidir, demekte; bu sözlerinin hemen ardından ikinci bir rivayet vererek bu rivayette "ismi ismime uygun" ifadesinin bulunmadığını belirtmektedir. ${ }^{71}$ Burada "ismi ismime, babasının ismi babamın ismine uygun" ifadesinin yer aldığı bir mehdi rivayeti söz konusu edilmemektedir.

Muhammed b. Abdullah'ın ailesi (ehl-i beyt) tarafından Mehdi olarak isimlendirildiğini, ailesinin bu algıyı yaydığını ve onun Mehdiliği konusunda kimsenin şüphesi bulunmadığını, bu sebeple Abbâsoğullarına varıncaya kadar Haşimoğullarının kendisine biat ettiğini söyleyen Ebü'l-Ferec elİsfahânî, "Onun Mehdi Olarak İsimlendirilişi İle İlgili Söylenenler" başlığı altında, onun mehdiliğine işaret eden rivayetleri vermektedir. ${ }^{72}$ Hatta babası önde gelen Haşimoğullarına oğlu Abdullah'ın mehdiliğini bildiklerini söylemekte ve onlardan oğluna biat etmelerini istemektedir. Hz. Ali ve Abbâsoğullarının önde gelenlerinin bulunduğu bu Ebvâ'daki toplantıda, Ca'fer es-Sâdık hilafet işinin Abbâsoğullarında olacağını söylemiştir, ancak rivayete göre oradakilerin hepsi Muhammed'e biat etmişlerdir. ${ }^{73}$ Ancak aynı kitabın başka yerlerinde Ca'fer es-Sâdık'ın Muhammed'e biat ettiği ve mehdi dediği şeklinde rivayetler de yer almaktadır. Onun mehdiliği ile ilgili "Bu konuda rivayetler çoktur, bizim verdiklerimiz yeterlidir." diyen ${ }^{74}$ Ebü'l-Ferec el-İsfahânî'nin kitabında dikkat çeken bir husus, Muhammed b. Abdullah'ın mehdi oluşuna dair birçok ifade ve olay yer almasına rağmen çalışmamıza konu olan "ismi ismime, babasının ismi babamın ismine uygun" ifadesi yer almamasıdır.

Hatîb el-Bağdâdî, (öl. 463/1071) Abbâsî Halifesi Mehdi'den bahsederken ilgili rivayetimizi nakleder ve böylece rivayetin gösterdiği kişi ile ilgili tarafını açıkça ortaya koyar. ${ }^{75}$ Hatîb el-Bağdâdî’den naklederek aynı

${ }^{71}$ Ebû Nasr el-Mutahhar b. Tâhir el-Makdisî, el-Bed'ü ve't-Târîh (Porsaid: Mektebetü'sSekâfeti'd-Diniyye, t.y.), 2: 180-181.

72 Ebü'l-Ferec el-İsfahânî, Mekâtilü't-Tâlibiyyîn, 207, 210-216.

73 Ebü'l-Ferec el-İsfahânî, Mekâtilü't-Tâlibiyyîn, 185-186, 224.

74 Ebü'l-Ferec el-İsfahânî, Mekâtilü't-Tâlibiyyîn, 187-188.

75 Ebû Bekr Ahmed b. Alî Hatîb el-Bağdâdî, Târîhu Bağdâd, thk. Beşşâr Avvâd Ma'rûf (Beyrut: Dâru'l-Garbi'l-İslâmî, 2002), 3: 282. 
rivayeti İbn Asâkir (öl. 571/1176) vermiş76 ve rivayeti Abbâsî Halifesi Mehdi ile ilişkilendirmişlerdir. Benzer bir şekilde çok yönlü bir âlim olan İbnü'lCevzî, (öl. 597/1201) Zâide > Âsım > Ebû Vâil > Abdullah b. Mes'ûd senediyle Hz. Peygamber'in "Mehdi'nin ismi ismime, babasının ismi babamın ismine uygundur." rivayetini Abbâsî Halifesi Mehdi ile ilgili söylemiş ve rivayetin ardından Halife Mehdi'nin çocukları ve annelerinden bahsetmiştir. ${ }^{77}$ Söz konusu tarihçiler, mehdi rivayetini Halife Mehdi için kullanmalarıyla farklılık arz etmekte, rivayetin anlaşılmasında Abbâsî Halifesi Mansûr'un arzu ettiği çizgide hareket etmektedirler.

Hz. Ali taraftarlığı ön planda olan bir başka tarihçi İbnü't-Tıktakâ da (öl. 709/1309) işin başında insanlar arasında Muhammed Nefsü'zZekiyye'nin müjdelenen Mehdi olduğu fikrinin yayıldığını, babasının da bunu farklı grupların benimsemesini sağladığını söylemektedir. Ona göre bu arada Hz. Peygamber'in "Dünyanın son günü olsa dahi Allah o günü uzatır nihayetinde ismi ismime, babasının ismi babamın ismine uygun Mehdimizi veya onun vekilini gönderir." sözü rivayet edilmekteydi. Muhammed'in babası Abdullah insanlara oğlu Muhammed ile ilgili "Bu şahıs yani müjdelenen Mehdi, Muhammed b. Abdullah'tır." diyordu. ${ }^{78}$

Hem hadisçi hem tarihçi kimliğiyle tanınan Zehebî, İbnü'l-Cevzî̀nin verdiği senedle Hz. Peygamber'in "Mehdi'nin ismi ismime, babasının ismi babamın ismine uygundur." rivayetini Ebû Dâvud ve Tirmizî'nin eserlerinde tahric ettiğini ve Tirmizî’nin söz konusu rivayete sahih hükmü verdiğini söyler. 0 da İbnü'l-Cevzî gibi rivayeti Abbâsî Halifesi Mehdi ile ilişkili olarak verir. ${ }^{79}$ İlginç bir biçimde Zehebî, 357 yılı olaylarını anlatırken Abbâsî Halifesi Müstekfî, (öl. 338/949) görevinden azledilip gözlerine mil çekildikten ve hapiste öldükten sonra, oğlu Ebü'l-Hasan Muhammed b. Abdullah'a bir grup insanın Hz. Peygamber'in "Benden sonra gelecek olan Mehdi'nin ismi ismime, babasının ismi babamın ismine uygun olacaktır." sözünü söyleyerek onu halifeliğe çağırdıklarını nakletmektedir. ${ }^{80}$ Böylece

76 İbn Asâkir, Târîhu Medîneti Dımeșk, 53: 414; Ebü'l-Fazl Cemâlüddîn Muhammed b. Mükerrem İbn Manzûr, Muhtasaru Târîhi Medîneti Dımeșk, thk. Rûhiyye en-Nehhâs vd. (Dımeșk: Dâru'l-Fikr, 1984), 22: 298.

77 Ebü'l-Ferec Cemâlüddîn Abdurrahmân b. Ali İbnü'l-Cevzî, el-Muntazam fî Târîhi'l-Mülûk ve'l-Ümem, thk. Muhammed Abdülkadir Atâ-Mustafa Abdülkadir Atâ (Beyrut: Dârü'lKütübi'l-İlmiyye, 1992), 8: 206.

78 Muhammed b. Ali b. Tabâtabâ İbnü't-Tıktakâ, el-Fahrî fi'l Adâbi's-Sultâniyye ve'dDüveli'l-IIslâmiyye, thk. Abdülkadir Muhammed Mâyû (Beyrut: Dâru'l-Kalemi'l-Arabî, 1997), 163.

79 Zehebî, Târîhu'l-İslâm, 10: 436.

80 Zehebî, Târîhu'l-İslâm, 26: 39. 
söz konusu rivayetin Muhammed Nefsü'z-Zekiyye ve Halife Mehdi'den sonra üçüncü bir şahıs için daha kullanıldığını görmekteyiz. Bu yaklaşım da bize rivayetin shhhatinden ziyade siyaset malzemesi hâline getirildiğini ve istismar edilerek kullanıldığını göstermektedir. Bu algı da rivayetin aslını araştırmak yerine yayılmasını sağlamış gibi görünmektedir.

Birçok sahada otorite olmakla birlikte hadisçi ve tarihçiliğiyle maruf İbn Kesîr, mehdinin Şiîlerin beklediği beș yaşında iken bir dehlize giren Muhammed b. Hasan olmadığını, onun kıyamet öncesinde geleceğini ifade ettikten sonra bizim de yukarıda verdiğimiz rivayetleri senediyle nakleder. İbn Kesîr, mehdinin Hz. İsa'nın gelişinden önce geleceğini düşünür ve ne Muhammed Nefsü'z-Zekiyye'yi ne de Abbâsî Halifesi Mehdi'yi konumuz olan "İsmi ismime uygun, babasının ismi babasının ismine uygun" mehdi rivayetleriyle ilișkilendirir. ${ }^{81}$

Mehdi rivayetlerini ilk defa eleștirdiği ifade edilen ve kitabında mehdi rivayetlerinin senetleriyle ilgili hadis otoritelerinin açıklamalarına yer veren İbn Haldûn, söz konusu rivayetlerimizi de nakleder ve daha çok kıraat âlimi Âsım üzerinden "ismi ismime, babasının ismi babamın ismine uygun" rivayetini eleştirir. ${ }^{82}$ Süyûti ise Zehebî'nin eserinden aynı bilgileri isim vererek alıntılar. ${ }^{83}$

Tarihî rivayetlerden anlaşıldığı kadarıyla Muhammed b. Abdullah, Alioğullarından bir temsilci olarak Abbâsîlere karşı fikri olarak mücadelesini başlatırken mehdiliği kullanmıştır. Belâzurî’nin rivayetini dikkate alacak olursak bunu ilk olarak Mugîre b. Saîd başlatmıştır. Burada söz konusu kişinin hadis uyduran aşırı bir Râfizî ve çok yalancı (kezzâb) olduğu bilgisini burada hatırlamamız icap edecektir. ${ }^{84} \mathrm{O}$ kadar müfrittir ki taraftarlarına Hz. Ali'nin geçmiş bütün peygamberlerde üstün olduğunu 85 ve ölüleri diriltebildiğini söyleyebilmektedir. ${ }^{86}$ Muhammed Nefsü'z-Zekiyye'nin mehdiliğini muhtemelen Mugîre'nin ardından babası Abdullah b. Hasan b. Hasan her ortamda gündeme getirmiş, zamanla Medineliler başta olmak üzere ciddi bir halk kitlesi onu Mehdi olarak görmüşlerdir. Muhammed b. Abdullah da Mansûr ile mektuplaşmalarında kendisini "Mehdi" olarak

81 Ebü'l-Fidâ İsmail b. Ömer İbn Kesîr, en-Nihâye fi'l-Fiten ve'l-Melâhım, thk. Muhammed Ahmed Abdülaziz (Beyrut: Dâru'l-Ceyl, 1988), 1: 51.

82 İbn Haldûn, Kitâbü'l-Iber, 1: 388-399.

83 Süyûtî, Târîhu'l-Hulefâ', 202.

84 İbn Ebî Hâtim, el-Cerh ve't-Ta'dîl, 8: 223; İbn Hıbbân, Mecrûhîn, 3: 8.

85 Ebû Ahmed Abdullâh İbn Adî, el-Kâmil fî Du'afâ'i'r-Ricâl, thk. Âdil Ahmet AbdülmevcûdAli Muhammed Muavvaz (Beyrut: Dâru'l-Kütübi'l-İlmiyye, 1997), 8: 82; Zehebî, Mîzânü'lI'tidâl, 4: 161.

86 İbn Hıbbân, Mecrûhîn, 3: 7; İbn Adî, el-Kâmil, 8: 82. 
tanıtmıştır. Siyasî çekişmenin mehdilik argümanı ile dinî alandan delillerle desteklenmeye çalışılmış ve sadece Muhammed b. Abdullah'ın mehdi olduğunu ifade edilen rivayetler $\mathrm{Hz}$. Peygamber'e söyletilmeye başlanmıştır. ${ }^{87}$ "İsmi benim ismime, babasının ismi babamın ismine uygun" yani Muhammed b. Abdullah'ın mehdiliği Hz. Peygamber'e tasdik ettirilmiştir.

Muhammed hayatta iken onun mehdi olduğu görüşünde olan ve bu konuda "ismi ismime, babasının ismi babamın ismine uygun" ifadesinin yer aldığı rivayeti delil getiren Mugîre b. Saîd vefat ettikten sonra onun taraftarları, Muhammed'in ölümüyle beraber iki gruba ayrılmıştır: Bir grup söz konusu ölümle birlikte Mugîre'nin onun mehdi olacağı ve yeryüzünü adaletle dolduracağı görüşünü reddederek ayrılmıştır. İkinci bir grup ise Muhammed Nefsü'z-Zekiyye'nin ölmediğine Necd yakınlarındaki Hâcir Dağı'nda yaşadığına ve tekrar ortaya çıkması emredildiğinde gelip dünyaya hâkim olacağına inanmışlardır. Onlara göre Muhammed, Mekke'de Rukn ile Makam arasında kendisine biat edildikten sonra on yedi ölüyü diriltecek, bunların her birine el-İsmü'l-A'zam'ın harflerinden biri verilecek ve onlar da orduları bozguna uğratarak yeryüzünde Mesih çağını tesis edeceklerdir. "Muhammediyye" adı verilen bu gruba göre Abbâsîlerin öldürdüğü kişi Muhammed b. Abdullah b. Hasan değildir. Onlar, Muhammed b. Abdullah'ın tekrar dünyaya geleceğini beklemektedirler ki bunların başında Câbir b. Yezîd el-Cu'fî gelmektedir. ${ }^{88}$ Mugîre b. Saîd'i imam olarak kabul etmeleri sebebiyle Mugîriyye de denilen bu gurubun görüşlerinin Zerdüşt ve Maniheist fikirlerden etkilendiği söylenilmektedir. ${ }^{89}$ Zeydiyye'nin Carüdiyye fırkasının da Muhammed b. Abdullah'ın ölmediğine, yeryüzünü adaletle doldurmadan da ölmeyeceğine inandıkları ifade edilmektedir. ${ }^{90}$ Böylece Muhammed b. Abdullah'ı gösteren mehdi rivayetleri, Şiîlerin kaynaklarına girmiştir. ${ }^{91}$

Öte taraftan Muhammed Nefsü'z-Zekiyye'nin mehdi algısı oluşturmaya başlaması üzerine rakibi Abbâsî Halifesi Mansûr Abdullah, aynı

87 Zorlu, Ísyanlar, 221.

88 Ebû Mansûr b. Tâhir et-Temîmî Abdülkâhir el-Bağdâdî, el-Fark beyne'l-Fırak, 2. Bs (Beyrut: Dâru'l-Âfâkı'l-Cedîde, 1977), 1: 43-45; Ebü'l-Feth Tâcüddîn Muhammed b. Abdilkerîm Șehristânî, el-Milel ve'n-Niḥal (Mektebetü'ş-Șâmile, t.y.), 1: 177.

${ }^{89}$ William F. Tucker, "Asiler ve Gnostikler: el-Muğire İbn Sa'id ve Muğiriyye”, Ankara Üniversitesi İlahiyat Fakültesi İslam İlimleri Enstitüsü Dergisi, trc. Ethem Ruhi Fığlalı 5 (1982): 206, 208, 211, 216; Topaloğlu, "Şîa'daki Mehdi İnancı", 109.

|26| 90 Mustafa Öz, "Muhammed b. Abdullah el-Mehdi”, TDV İslâm Ansiklopedisi (İstanbul: TDV Yayınları, 2005), 30: 490.

${ }_{91}$ Avni İlhan, Mehdîlik (İstanbul: Akyay Kaynak Yayınları, 1976), 86. 
rivayetleri muhtemelen oğlu Muhammed'e uygunluğu sebebiyle kullanmaya başlamıştır. Muhammed Nefsü'z-Zekiyye'ye karşı kazandığı zaferle mehdiye benzer bir anlamda "Mansûr" lakabını alan Ebû Ca'fer, onun mehdiliğini unutturmak adına oğluna "Mehdi" lakabını vermiştir. ${ }^{92}$ Halife, oğlu Muhammed'in mehdiliğini yaymış hatta şairleri bile bu yönde teşvik etmiştir. ${ }^{93}$ Böylece Abbâsî Halifesi'nin etkisiyle aynı rivayetler Sünnî hadis kaynaklarına dahil olmuş, hatta Ehl-i Sünnet'in meşhur altı kitabından bazılarında kendisine yer bulabilmiştir. Böylece, "Önce Şî̂ler, ardından Emevîler ve Abbâsîler arasında yayılan mehdî inancı, III. (IX.) yüzyılda hadislerin toplanıp kayda geçirilmesi ve hadislerin shhhati konusunda titiz davranmayan muhaddislerce mehdî rivayetlerinin mecmualara alınmasının ardından Sünnîler arasında da benimsenmeye başlanmıştır. Ancak erken devir Sünnî literatüründe bu inanca hemen hemen hiç temas edilmemiş, konu daha çok hadisçilerin dahil olduğu Selefiyye'ye ait eserlerde yer almıştır. Geç dönemde oluşan Sünnî kelâm literatürü ile "fiten ve melâhim" türü eserlerde ise mehdî telakkisinden genellikle kısaca bahsedilmiştir." 94 Belki de geçmiş toplumlarda da var olan bir kurtarıcı inancıyla ilgili Allah Rasulü, toplumun düzelmesi için adalet sahibi bir imamdan/devlet idarecisinden bahsetmiş; zamanla rivayetler mitolojik bir mehdiye dönüşmüştür. Rivayetlerdeki adalete vurgu ve insanların problemlerini çözmeye odaklanılması bu ihtimali güçlenmektedir. ${ }^{95}$ Adaletli devlet başkanıyla ilgili rivayetler, söz konusu dönüşüm esnasında toplumda derin izler bırakan siyasî olaylardaki tarafların haklılık veya haksızlığını ortaya koymak adına birilerini işaret eden rivayetlere evrilmiștir. Günümüzde hâlâ "ismi ismime, babasının ismi babamın ismine uygun" rivayeti istismar edilmekte ve bu ifade "Adnan" ismiyle uyuşturularak yeni mehdiler türetilmeye çalışılmaktadır. Konumuz olan mehdi rivayeti, Hz. Peygamber'in atalarından hareketle bir isminin de "Adnan" olduğu varsayımıyla, Adnan

92 Hüseyin Atvan, ed-Da'vetü'l-Abbâsiyye, Mebâdi' ve Esâlib, (Beyrut, 1984), 173-179; Ahmet Güzel, Abbâsî Halifesi Mehdi b. Mansûr (Konya: Kitap Dünyası Yayınları, 2012), 5657.

93 Abdülaziz ed-Dûrî, "Abbâsî Propagandası Sürecinde ve Abbâsîler'in İlk Asrında Mehdî Tasavvuru", Istem, trc. M. Bahaüddin Varol 2/3 (2004): 227-228; Ahmet Güzel, "Ebû Ca'fer el-Mansûr ve Muhammed en-Nefsüzzekiyye Arasındaki Siyasî Mücadelede Mehdî Anlayışının Rolü", Uluslararası Mehdilik Sempozyumu Bildirileri, ed. Mehmet Tıraşçı vd. (Sivas: Cumhuriyet Üniversitesi İlahiyat Fakültesi, 2018), 62.

94 Yusuf Şevki Yavuz, "Mehdi”, TDV İslâm Ansiklopedisi (İstanbul: TDV Yayınları, 2003), 28: 372.

${ }_{95}$ Ağırman, “Mehdî ile İlgili Rivayetler”, 2: 359. 
ismi taşıyanların istismar malzemesi hâline getirilmektedir. 96

\section{Sonuç}

"İsmi ismime, babasının ismi babamın ismine uygun" ifadesinin yer aldığı ve mehdiyi işaret eden rivayetler kütüb-i sitte eserlerinden Ebû Dâvud ve Tirmizî̀nin sünenlerinde ve başka hadis kaynaklarında geçmektedir. Bu çalışmada söz konusu rivayetler önce senet olarak ele alınmış ve ilgili rivayetlerin sened olarak hasen ve zayıf olduğu görülmüştür. Senet açısından hasen denebilecek rivayette dahi Ebü'n-Nücûd Âsım b. Behdele isimli meşhur kıraat âlimi olan ravinin, hadis konusunda özellikle konumuzun merkezini teșkil eden rivayetteki gibi Zir ve Ebû Vâil rivayetlerini karıştırması önemli bir husustur. Konuyla ilgili farklı dört zayıf rivayetin birbirini desteklediği ve hasen mertebesine çıkardığı düşüncesi, söz konusu rivayetin farklı ve hasen denebilecek rivayetlere muhalefeti sebebiyle kanaatimizce geçerli olmayacaktır. Ayrıca söz konusu senetlerde sadece Kûfelilerin bulunması, Medineli hiçbir ravinin bulunmaması "ismi ismime, babasının ismi babamın ismine uygun" ifadesinin yer aldığg mehdi rivayetlerinin Medine'de bilinmediğini göstermektedir. Oysaki rivayet daha çok Medine'de faaliyet gösteren Muhammed b. Abdullah ve ailesi tarafından kullanılan bir rivayet olmuştur. Konumuzu teşkil eden senet itibariyle rivayetler zayıftır ve değil inanç konusunda ahkam konusunda dahi delil olarak kabul edilemez.

Abbâsîlerin ikinci halifesi Ebû Ca'fer el-Mansûr'a karşı harekete geçen Hasanoğullarından Muhammed b. Abdullah'ın "ismi ismime, babasının ismi babamın ismine uygun" ifadesinin yer aldığı mehdi rivayetlerini kullandığ tarih kitaplarında tespit edilen bir vakıadır. Tespit edebildiğimiz kadarıyla rivayet, ilk defa Ya'kûbî gibi daha çok Hz. Ali taraftarı olan tarihçilerin kitaplarında yer alsa da Belâzurî, Taberî, İbnü'l-Cevzî, İbnü'l-Esîr, Zehebî, İbn Kesîr gibi tarihçilerin eserlerinde kendisine yer bulabilmiştir. Söz konusu kaynaklardaki ilginç bir durum, rivayetin çoğunlukla Muhammed b. Abdullah ile ilişkilendirilmesine karşın Hatîb el-Bağdâdî, İbn Asâkir ve İbnü'l-Cevzî gibi bazı tarihçiler tarafından Abbâsî Devleti'nin üçüncü halifesi Mehdi lakaplı Muhammed b. Abdullah Ebû Ca'fer el-Mansûr'u işaret eden bir rivayet olarak görülmesidir. Hatta Zehebî, rivayeti bir yandan Abbâsî Halifesi Mehdi ile ilişkilendirirken öte yandan Abbâsî Halifesi Müstekfî̀nin oğlu Ebü’l-Hasan Muhammed $b$. Abdullah için bir grup insan tarafından gündeme getirildiğini

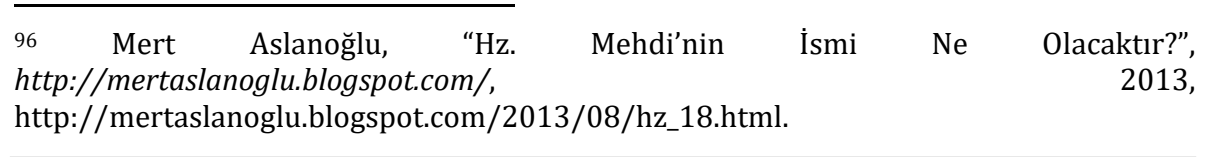


naklederek rivayetin Muhammed Nefsü'z-Zekiyye ve Halife Mehdi'den sonra üçüncü bir şahıs için daha kullanıldığını bize nakletmiş olmaktadır. Aslında bu durum söz konusu rivayetin, siyasete malzeme olarak kullanıldığını açıkça ortaya koymaktadır.

Söz konusu hadisin siyaset sebebiyle kullanılmasının serencamına baktığımızda, anlaşıldığı kadarıyla ilk defa mehdi konusunun gündeme getirildiği Muhtar b. Ebû Ubeyd ile Muhammed b. Hanefiyye arasındaki ilişkiye benzer bir șekilde rivayet, Mugîre b. Saîd tarafından kullanılmıştır. Buna göre Mugîre, siyasi hedeflerini gerçekleștirmek üzere yola çıkarken rivayeti uydurarak gündeme taşımış ve Muhammed b. Abdullah'ı mehdi ilan etmiştir. Daha sonra kendisini de mehdi ilan eden Mugîre'nin söz konusu hadis rivayeti, Muhammed Nefsü'z-Zekiyye'nin önce babası ve ailesi tarafından uygun görülmüş, sonra bir kısım halk tarafından da kullanılmaya başlanmıştır. Bu durum Muhammed b. Abdullah tarafından içselleştirilmiş, iktidara talip olan bu şahıs kendisi için kullanılan mehdi lakabına inanmış ve Ebû Ca'fer ile mektuplaşmalarında bunu kullanmıştır. Böylece rivayet Şî̂ eğilimli kaynaklarda kendisine yer bulurken, Abbâsî Halifesi Mehdi için kullanılmaya başlanmasıyla birlikte Sünnî kaynaklara da aktarılmıştır. Muhammed Nefsü'z-Zekiyye'nin bu rivayeti kullanması, karşı bir hareketle Abbâsî halifesinin de kullanmasına sebebiyet vermiştir. İlerleyen dönemde bazı Şiî grupların söz konusu mehdi rivayetlerini kullanması, tepkisel bir biçimde Sünnîlerin de rivayetleri kullanmasına sebep olmuş gibi görünmektedir.

Mehdi rivayetlerinin zayıf da olsa kaynaklarda yer alması ise adaletli devlet idarecisinden bahseden Hz. Peygamber sözlerinin, zulüm ve sıkıntıların çoğaldığı dönemlerde genelde farklı din ve inançlardan, özelde ise Şîa'dan geçtiği kabul edilen kurtarıcı fikrine evrilmesi sebebiyle olabilir. Adil devlet adamı profilinin kurtarıcı mehdi şekline dönüşmesi ise Muhammed Nefsü'z-Zekiyye, Halife Mehdi gibi siyasi özellikleri ön planda olan kişilerin isim ve özelliklerine uygun hâle getirilmesiyle olmuş gibidir. Böylece konumuzu teşkil eden ve mehdi rivayetlerinden sadece bir grubunu teşkil eden "ismi ismime, babasının ismi babamın ismine uygun" rivayetleri ortaya çıkmış görünmektedir. Bu arada Ehl-i sünnet ile Şîa arasında tartışma konusu da olan ancak rivayetin sıhhatinden çok kim olduğuna yönelik tartışmalar, rivayetleri mutlak doğru gibi göstermiş̧tir.

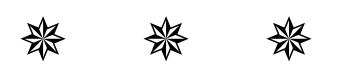


Mithat ESER

\section{KAYNAKÇA}

Abdülkâhir el-Bağdâdî, Ebû Mansûr b. Tâhir et-Temîmî. el-Fark beyne'l-Fırak. 2. Bs. Beyrut: Dâru'l-Âfâkı'l-Cedîde, 1977.

Abdülmuhsin b. Hamd. Şerhu Süneni Ebî Dâvud. el-Mektebetü'ş-Şamile, t.y.

AĞIRMAN, Cemal. "Kütüb-i Tis'a Kaynaklarında Yer Alan Mehdî ile İlgili Rivayetlerin Değerlendirilmesi ve Bu Rivayetlerle İlgili Yapılan Yorumlar". Uluslararası Mehdilik Sempozyumu Bildirileri. Ed. Mehmet Tıraşçı vd. 2: 336-362. Sivas: Cumhuriyet Üniversitesi İlahiyat Fakültesi, 2018.

Ahmed b. Hanbel, Ebû Abdillâh. el-Ilel ve Ma'rifeti'r-Ricâl. Thk. Vasıyyüllâh b. Muhammed Abbâs. 2. Bs. Riyad: Dâru'l-Hânî, 2001.

Ahmed b. Hanbel, Ebû Abdillâh. Müsnedü Ahmed. Beyrut: Müessesetü'rRisâle, 2001.

AKGÜN, Hüseyin. "Mehdilik Hadislerinin Hadis Rivayet Coğrafyası Açısından İncelenmesi". Hadis ve Siyer Araștırmaları Dergisi 5/2 (2019): 311331.

Ali el-Kârî, Ebü'l-Hasen Nûrüddîn. Mirkâtü'l-Mefâtîh Şerhu Mişkâtü'lMesâbîh. Beyrut: Dâru'l-Fikr, 2002.

ASLANOĞLU, Mert. "Hz. Mehdi'nin İsmi Ne Olacaktır?" http://mertaslanoglu.blogspot.com/. 2013. http://mertaslanoglu.blogspot.com/2013/08/hz_18.html.

AȘIKKUTLU, Emin. "Cerh ve Ta'dîl”. TDV İslâm Ansiklopedisi. 7: 394-401. İstanbul: TDV Yayınları, 1993.

ATVAN, Hüseyin. ed-Da'vetü'l-Abbâsiyye, Mebâdi've Esâlib,. Beyrut, 1984.

AYDINLI, Abdullah. "Muan'an". TDV İslâm Ansiklopedisi. 30: 326. İstanbul: TDV Yayınları, 2005.

AZÎMÂBÂDÎ, Ebü't-Tayyib Muhammed Şemsü'l-Hak b. Emîr Alî. Avnü'lMa'bûd Şerhu Süneni Ebî Dâvud. Beyrut: Dâru'l-Kütübi'l-Ilmiyye, 1415.

BELÂZÛRî, Ebü'l-Abbas Ahmed b. Yahyâ b. Câbir el-. Ensâbü'l-Eşrâf. Thk. Süheyl Zekkar- ve Riyad ez-Ziriklî. Beyrut: Dârü'l-Fikr, 1996.

BESTEVÎ, Abdülalîm Abdülazîm. el-Mehdiyyü'l-Müntezar fí Davi'l-Ehâdîs ve'lÂsâri's-Sahîha. Mekke: Dâru İbn Hazm, 1999.

BESTEVÎ, Abdülalîm Abdülazîm. el-Mevsûa fî Ehâdîsi'l-Mehdî ed-Daîfeti ve'lMevdûati. Mekke: Dâru İbn Hazm, 1999.

BEZZÂR, Ebûbekir Ahmed b. Amr el-Basrî el-. Müsnedü'l-Bezzâr. Medine: Mektebetü'l-Ulûm ve'l-Hıkem, 2009. 
BOZKURT, Nahide. Oluşum Sürecinde Abbâsî İhtilali. Ankara: Ankara Okulu Yayınları, 2000.

ÇELİK, Ali. “Nuaym bin Hammâd'ın Hadisçiliği ve 'Kitâbu'l-Fiten'i Üzerine Bir Değerlendirme”. Dinî Araştırmalar 2/6 (2000): 99-118.

DÂREKUTNÎ, Ebü'l-Hasen Alî b. Ömer. el-Ilelü'l-Vâride fî Ehâdîsi'n-Nebeviyye. Thk. Mahfûzurrahmân Zeynullah es-Selefî. Riyad: Dâru Taybe, 1985.

DÛRÎ, Abdülaziz ed-. "Abbâsî Propagandası Sürecinde ve Abbâsîler'in İlk Asrında Mehdî Tasavvuru”. İstem. Trc. M. Bahaüddin Varol 2/3 (2004): 219-231.

DURMUŞ, Mehmet Ali. Mitolojik Kurtarıcı Mehdi. 2. Bs. İstanbul: İşaret Yayınları, 2015.

Ebû Züraa, Ubeydullâh b. Abdilkerîm er-Râzî. Kitâbü'd-Duafâ'. Medine: Imâdetü'l-Bahsi'l-Ilmî, 1992.

Ebü'l-Ferec el-İsfahânî, Alî b. el-Hüseyn. Mekâtilü't-Tâlibiyyîn. Beyrut: Dâru'lMarife, t.y.

EREN, Muhammed Emin. “Olgudan Rivayete Ya da Yorumun Rivayetleşmesi: Nu'aym b. Hammâd'a Ait Bir Rivayetin Tahlili". Isslam ve Yorum -Temel Tartışmalar, Imkanlar ve Sorunlar-. Ed. Fikret Karaman. 2: 651-661. Ankara: TDV Yayınları, 2017.

ESER, Mithat. Abbâsîlerin İlk Döneminde Seyyidler ve Şerifler. İstanbul: İz Yayıncllık, 2014.

GÜNEŞ, Hüseyin. "İslam Tarihinin İlk Mehdisi: Muhammed b. Hanefiyye”. Uluslararası Mehdilik Sempozyumu Bildirileri. Ed. Mehmet Tıraşçı vd. 136-158. Sivas: Cumhuriyet Üniversitesi İlahiyat Fakültesi, 2018.

GÜZEL, Ahmet. Abbâsî Halifesi Mehdi b. Mansûr. Konya: Kitap Dünyası Yayınları, 2012.

GÜZEL, Ahmet. “Ebû Ca'fer el-Mansûr ve Muhammed en-Nefsüzzekiyye Arasındaki Siyasî Mücadelede Mehdî Anlayışının Rolü". Uluslararası Mehdilik Sempozyumu Bildirileri. Ed. Mehmet Tıraşçı vd. 49-66. Sivas: Cumhuriyet Üniversitesi İlahiyat Fakültesi, 2018.

Hatîb el-Bağdâdî, Ebû Bekr Ahmed b. Alî. Târîhu Bağdâd. Thk. Beşşâr Avvâd Ma'rûf. Beyrut: Dâru'l-Garbi'l-İslâmî, 2002.

ICLî, Ebü'l-Hasen Ahmed b. Abdillâh el-. Târîhu's-Sikât. Mekke: Dâru'l-Bâz, 1984.

İbn Adî, Ebû Ahmed Abdullâh. el-Kâmil fí Du'afầi'r-Ricâl. Thk. Âdil Ahmet Abdülmevcûd-Ali Muhammed Muavvaz. Beyrut: Dâru'l-Kütübi'l- 
İlmiyye, 1997.

İbn Asâkir, Ebü'l-Kâsım Alî b. el-Hasen ed-Dımaşkî eş-Şâfiî. Târîhu Medîneti Dımeșk. Thk. Ömer b. Garâme el-Amravî. Beyrut: Dâru'l-Fikr, 1995.

İbn Ebî Hâtim, Ebû Muhammed Abdurrahmân b. Muhammed er-Râzî. el-Cerh ve't-Ta'dîl. Haydarâbâd: Tab'atü Meclisi Dâireti'l-Meârifi'l-Osmânî, 1952.

İbn Ebî Şeybe, Ebû Bekr Abdullâh b. Muhammed el-Absî el-Kûfî. Müsnedü İbn Ebî Şeybe. Riyad: Dâru'l-Vatan, 1997.

İbn Hacer el-Askalânî, Ebu'l-Fadl Ahmed b. Ali. el-İsâbe fî Temyîzi's-Sahâbe. Thk. Âdil Ahmed Abdülmevcûd-Ali Muhammed Muavvaz. Beyrut: Dâru'l-Kütübi'l-Ilmiyye, 1415.

İbn Hacer el-Askalânî, Ebu'l-Fadl Ahmed b. Ali. Tehzîbü't-Tehzîb. Hindistan: Matbaatü Dâireti'l-Meârifi'n-Nizâmiyye, 1326.

İbn Haldûn, Ebû Zeyd Veliyyüddîn Abdurrahmân b. Muhammed el-Hadramî el-Mağribî et-Tûnis. Kitâbü'l-Iber ve Dîvânü'l-Mübtede’ ve'l-Haber fî Eyyâmi'l-Arab ve'l-Acem ve'l-Berber ve men-Âsârahüm min-zevi'sSulțâni'l-Ekber. Beyrut: Dâru'l-Fikr, 1988.

İbn Hıbbân, Ebû Hâtim Muhammed. el-Mecrûhîn mine'l-Muhaddisîn. Thk. Hamdî Abdülmecîd es-Selefî. Riyad: Dâru's-Sumayî, 2000.

İbn Hıbbân, Ebû Hâtim Muhammed b. Hibbân el-Büstî. Kitâbü's-Sikât. Haydarâbâd: Dâiratü'l-Meârifi'l-Osmâniyye, 1973.

İbn Kesîr, Ebü'l-Fidâ İsmail b. Ömer. en-Nihâye fi'l-Fiten ve'l-Melâhım. Thk. Muhammed Ahmed Abdülaziz. Beyrut: Dâru'l-Ceyl, 1988.

İbn Manzûr, Ebü'l-Fazl Cemâlüddîn Muhammed b. Mükerrem. Muhtasaru Târîhi Medîneti Dımeșk. Thk. Rûhiyye en-Nehhâs vd. Dımeșk: Dâru'lFikr, 1984.

İbn Miskeveyh, Ebû Alî Ahmed b. Muhammed el-Hâzin. Tecâribü'l-Ümem ve Te âkibü'l-Himem. Thk. Ebü'l-Kasım İmâmî. 2. Bs. Tahran: Serûş, t.y.

İbn Receb el-Hanbelî, Ebü'l-Ferec Zeynüddîn Abdurrahmân b. Ahmed. Şerhu Ileli't-Tirmizî. Zerkâ: Mektebetü'l-Menâr, 1987.

İbn Sa'd, Ebû Abdillâh Muhammed. et-Tabakâtü'l-Kübrâ. Beyrut: Dâru'lIlmiyye, 1990.

İbn Şâhîn, Ebû Hafs Ömer b. Ahmed el-Bağdâdî. Târîhu Esmâi's-Sikât. Thk. Subhî es-Sâmerrâî. Kuveyt: ed-Dâru's-Selefiyye, 1984.

İbn Teymiye, Ebü'l-Abbâs Takıyyüddîn Ahmed b. Abdilhalîm. Minhâcü'sSünneti'n-Nebeviyye, Thk. Muhammed Reşad Sâlim. Riyad: Câmiatü'l- 
İmam Muhammed b. Suudü'l-İslamiyye, 1986.

İbnü'l-Cevzî, Ebü'l-Ferec Cemâlüddîn Abdurrahmân b. Ali. el-Muntazam fî Târîhi'l-Mülûk ve'l-Ümem. Thk. Muhammed Abdülkadir Atâ-Mustafa Abdülkadir Atâ. Beyrut: Dârü'l-Kütübi'l-İlmiyye, 1992.

İbnü'l-Esîr, İzzuddin Ebu'I-Hasan Ali b. Muhammed. el-Kâmil fi't-Târîh. Beyrut: Dâru'l-Kütübi'l-Illmiyye, 2010.

İbnü't-Tıktakâ, Muhammed b. Ali b. Tabâtabâ. el-Fahrî fi'l Adâbi's-Sultâniyye ve'd-Düveli'l-İslâmiyye. Thk. Abdülkadir Muhammed Mâyû. Beyrut: Dâru'l-Kalemi'l-Arabî, 1997.

ILHAN, Avni. "Kütübü Sittedeki Hadislere Göre Mehdilik". Dokuz Eylül Üniversitesi İlahiyat Fakültesi Dergisi. 7 (1992): 101-124.

İLHAN, Avni. Mehdîlik. İstanbul: Akyay Kaynak Yayınları, 1976.

KILIÇ, Hulusi. “Ebü'l-Ferec el-İsfahânî”. TDV İslâm Ansiklopedisi. 10: 316-318. İstanbul: TDV Yayınları, 1994.

MAKDİSî, Ebû Nasr el-Mutahhar b. Tâhir el-. el-Bed'ü ve't-Târîh. Porsaid: Mektebetü's-Sekâfeti'd-Diniyye, t.y.

MES'ÛDÎ, Ebü'l-Hasan Ali b. Hüseyin el-. et-Tenbîh ve'l-İsrâff. Thk. Abdullah İsmâil es-Sâvî. Kahire: Mektebetü'ş-Şarkı'l-İslâmiyye, 1938.

MiZZÎ, Ebü'l-Haccâc Cemâlüddîn Yûsuf b. Abdirrahmân el-. Tehzîbü'l-Kemâl fí Esmâi'r-Ricâl. Beyrut: Müessesetü'r-Risâle, 1980.

Muhsin el-Emîn, Ebû Muhammed el-Bâkır. A'yânü'ş-Şîa. Thk. Hasan el-Emîn. Beyrut, 1986.

Nuaym b. Hammâd, Ebû Abdillâh el-Huzâî el-Mervezî. Kitâbü'l-Fiten. Kahire: Mektebetü't-Tevhîd, 1412.

ÖZ, Mustafa. "Muhammed b. Abdullah el-Mehdi". TDV İslâm Ansiklopedisi. 30: 489-490. İstanbul: TDV Yayınları, 2005.

SAFEDÎ, Salâhuddîn Halil b. Aybek. Kitabü'l-Vâfi bi'l-Vefeyât. Thk. Ahmed Arnaûd- ve Mustafa Türkî. Beyrut: Dâru İhyâi't-Türâs, 2000.

SÜYÛTî, Celâlüddîn Abdurrahmân b. Ebî Bekr es-. el-Urfü'l-Verdî fí ahbâri'lMehdî. Beyrut: Dâru'l-Kütübi'l-Ilmiyye, 2006.

SÜYÛTî, Celâlüddîn Abdurrahmân b. Ebî Bekr es-. Târîhu'l-Hulefâ'. Thk. Hamdi Demirtaş. Mekke: Mektebetü Nizâr Mustafa el-Bâz, 2004.

ŞEHRISTÂNî,, Ebü'l-Feth Tâcüddîn Muhammed b. Abdilkerîm. el-Milel ve'nNiḥal. Mektebetü'ş-Şâmile, t.y.

TABERÂNî, Ebü'l-Kâsım Müsnidü'd-dünyâ Süleymân b. Ahmed. Mu'cemü'l- 
Kebîr. Thk. Hamdi Abdülmecit. Kahire: Mektebetü İbn Teymiye, 1994.

TABERÎ, Ebû Cafer İbn Cerîr Muhammed b. Cerîr b. Yezîd. Târîhu'l-Ümem ve'lMülûk. 2. Bs. Beyrut: Dâru't-Türâs, 1387.

TOPALOĞLU, Fatih. "Şîa'daki Mehdi İnancının Zerdüştlükle İlișkisi". Uluslararası Mehdilik Sempozyumu Bildirileri. Ed. Mehmet Tıraşçı vd. 101-116. Sivas: Cumhuriyet Üniversitesi İlahiyat Fakültesi, 2018.

TUCKER, William F. "Asiler ve Gnostikler: el-Muğire İbn Sa'id ve Muğiriyye”. Ankara Üniversitesi İlahiyat Fakültesi İslam İlimleri Enstitüsü Dergisi. Trc. Ethem Ruhi Fığlalı 5 (1982): 203-216.

UKAYLÎ, Ebû Ca'fer Muhammed b. Amr. ed-Duafâü'l-Kebîr. Thk. Abdülmu'tî Emin el-Kal'acî. Beyrut: Dâru'l-Mektebeti'l-Ilmiyye, 1984.

UYAR, Gülgün. Ehl-i Beyt, İslam Tarihinde Ali-Fatıma Evladı. İstanbul: Gelenek Yayınları, 2004.

VAROL, M. Bahaüddin. Hilafet Mücadelesinde Ehl-i Beyt Nesli. Konya: Yediveren Kitap, 2004.

YA'KÛBÎ, Ahmed b. Ebî Ya'kûb b. Ca'fer el-. Târihu'l-Ya'kûbî. Beyrut, 1995.

YAVUZ, Yusuf Şevki. "Mehdi". TDV İslâm Ansiklopedisi. 28: 371-374. İstanbul: TDV Yayınları, 2003.

YILMAZ, Orhan. "Mehdi İnancına Kaynaklık Teşkil Eden Hadislerin Değeri". Turkish Studies International Periodical for the Languages, Literature and History of Turkish or Turkic 12/2 (2017): 265-282.

YÜCEL, Ahmet. "Mehdi Hadislerinin Temel Kaynaklarındaki Anlamı". Beklenen Kurtarıcı Ínancı. 141-173. Editör: Yusuf Şevki Yavuz. İstanbul: Kuramer Yayınları, 2017.

ZEHEBÎ, Ebû Abdillâh Şemsüddîn Muhammed b. Ahmed ed-Dımaşkî ez-. Mîzânü'l-I'tidâl fî Nakdi'r-Ricâl. Thk. Ali Muhammed el-Bicâvî. Beyrut: Dârü'l-Ma'rife, 1963.

ZEHEBÎ, Ebû Abdillâh Şemsüddîn Muhammed b. Ahmed ed-Dımaşkî ez-. Siyeru A'âmi'n-Nübelâ. Thk. Şuayb el-Arnaût. Beyrut: Müessesetü'rRisâle, 1985.

ZEHEBÎ, Ebû Abdillâh Şemsüddîn Muhammed b. Ahmed ed-Dımaşkî ez-. Târîhu'l-İslâm. Thk. Ömer Abdüsselâm et-Tedmürî. 2. Bs. Beyrut: Dâru'l-Kütübi'l-Arabî, 1993.

ZEHEBÎ, Ebû Abdillâh Şemsüddîn Muhammed b. Ahmed ed-Dımaşkî ez-. Tehzîbü Tehzîbi'l-Kemâl fi Esmâi'r-Ricâl. Kahire: el-Fârûku'l-Hadîsiyye li't-Tıbâati ve'n-Neşr, 2004. 
ZíRİKLÎ, Hayruddîn. el-A'lâm: Kâmûsu Terâcim li-Eşheri'r-Ricâl ve'n-Nisâ mine'l-Arabi'l-Müsta'ribîn ve'l-Müsteşrikîn. 15. Bs. Beyrut: Dâru'l-Ilm li'l-Melâyîn, 2002.

ZORLU, Cem. Abbâsîlere Yönelik Dinî ve Siyasî İsyanlar. Ankara: Ankara Okulu Yayınları, 2001.

淡深 


\title{
MUHAMMAD B. ABDULLAH, THE FIRST MAHDI OF THE ABBASID PERIOD AND THE EVALUATION OF NARRATIVES ABOUT ITS MAHDIHOOD
}

\author{
(1) Mithat ESERa
}

\section{Extended Abstract}

Some of the Alids (descendants of Ali) were disappointed when the Abbasid State was established. Among them, Muhammad b. Abdullah (nicknamed as Al-Nafs al-Zakiyya) who was the grandson of Hasan acted against the Second Abbasid Caliph, Abu Jafar el-Mansur. During this political movement, the use of nickname 'mahdi' by Muhammad b. Abdullah for himself was included in our historical sources. The narrative that "the name matches my name, the name of his father matches my father's name" played an important role for him to get this nickname. So this narration was determined the name of mahdi as Muhammad b. Abdullah.

In our hadith sources, the perception of mahdihood which is stated as "the name matches my name, the name of his father matches my father's name", also takes place in different hadith sources. There are four different forms of this narration of which there is an alliance; but three of them are weak. There are different opinions about Abu'n-Nücûd Âsım b. Bahdala who is in the isnad of the narrative in the works of Abu Davud and Tirmidhi. Although the narrator in question is a good qiraah scholar, there is a controversy about his hadith profession. It is stated that he mixed the narrations which he conveyed from Zir, especially as in the narration of mahdi. In addition, there is a problem related to relevant narrations that those are conveyed by only narrators from Kufa. This means that it was used by Muhammad Al-Nafs alZakiyya and the narration was not known in Medina.

The narration of mahdi pointing to Abdullah was first mentioned by Mughira

a Assoc. Prof., Selçuk University, mithateser@hotmail.com 
b. Said. After Mughira, who will later use the same nickname for himself, mahdihood of Muhammad will also be accepted by his father and family. This opinion, which was accepted by some groups, was also accepted by Muhammad. Thus, he described himself as a mahdi in correspondence with the Abbasid caliph. In this way, the narrations of mahdi that started with Muhammad b. Abdullah were accepted by the Shia sources.

On the other hand, the mahdi narrations as "the name matches my name, the name of his father matches my father's name" were also used for Mahdi Muhammad b. Abdullah Abu Ja-far el-Mansur, the third caliph of the Abbasid. Thus, the same narration began to be seen in Sunni sources, and the narrations of mahdi which include the expression "the name matches my name, the name of his father matches my father's name", have taken place in the hadith sources. The common use of this narrative for two very important figures in history must have caused this narration to be mentioned in many works.

It is identified that the narrations related to our issue are primarily seen in the historical sources which are stated to be close to Shia. The first historical source in this manner is the work of Ya'qubi. Historians such as Abu'l-Faradi Isfahani, Mas'udi and Ibn Tiktaka, have included the mahdihood of Muhammad Al-Nafs al-Zakiyya in their books. In the sources of first period of Islamic history, the mentioned narration has been associated with the mahdihood of Muhammad Al-Nafs al-Zakiyya in the work of Baladhuri. Similarly, it was conveyed in the works of historians such as Baladhuri, Tabarî, Ibnü'l-Djavzî, Ibnü'l-Athîr, Dhahabî and Ibn Kathîr. However, some historians such as Hatîb Bagdâdî, Ibn Asâkir and Ibnü'l-Djavzî have associated this narration with the third Abbasid Caliph, Muhammad b. Abdullah. Furthermore, Dhahabi was associated the narration with Mahdi, the Abbasid Caliph while on the other hand, he also conveyed that it was used for Abu'l-Hasan Muhammad b. Abdullah who is the son of Mustakfi, the Abbasid Caliph. Thus, the relevant mahdi narration was used for a third person after Muhammad Al-Nafs al-Zakiyya and Caliph Mahdi. In fact, this clearly reveals that narration in question was used as an instrument for politics.

The relevant mahdi narration seems to have been formulated in accordance with politics. Thus, it seems that a religious reference was provided to some political figures. However, it is also important that the narrations of mahdi are also mentioned in many sources. Direct information about the mahdi is not included in the Quran. Similarly, it is not found in sahih hadith sources 
like Sahih of Bukhari and Muslim. However, it is included in many sources, especially the Sunans of Abu Davud and Tirmidhi. Many studies have been conducted about the narrations of the mahdi and different opinions have been reached. The idea of the weakness of the isnad of mahdi narrations, which was first mentioned by Ibn Khaldun, was also expressed by many contemporary researchers. First of all, it is certain that the perception of mahdi cannot be the subject of belief with the narrations which are controversial and many of them are weak. In addition, as it is the subject of our research, it is also possible that some additions were likely to be made into mahdi narrations in order to be an instrument for political conditions of the period. As a conclusion, it can be said about the mahdi narrations that "the hadiths said by the Prophet about the fair head of state were integrated with the idea of a savior over the time". Thus, the idea of a fair head of state has turned into a perception of a mahdi that would save the society. In this transformation, the influence of the Shia and the ancient Persian culture which was fed by Shia is particularly important.

In conclusion, mahdi narrations are generally problematic. Weak narrations cannot be an evidence of the belief. It is also controversial that the weak narrations are an evidence of judgment. Mehdi narrations as "the name matches my name, the name of his father matches my father's name" have been mentioned in a limited number in hadith sources. There is a problem in terms of isnad regarding each of them. From the point of view of the text, the relevant narration was said for Muhammad b. Abdullah who is accepted as the first mahdi of the Abbasid period. Later, the same narration was used for the Abbasid Caliph, Mahdi. Thus, the relevant narration has become widespread. It has been included in both Shia and Sunni sources. However, the historians are divided into two groups, about the person pointed out by the narration in question. The fact that the same narration was brought to the agenda for the son of Mustakfi, the Abbasid Caliph, also shows that the aforementioned narration was always used as an instrument of politics. Even today, it continues to be used based on the name 'Adnan'.

Keywords: Islamic History, Mahdihood, Muhammad Al-Nafs al-Zakiyya, Caliph Mahdi.

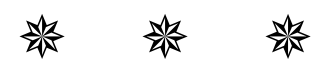

